\title{
Blue crab larval dispersal highlights population connectivity and implications for fishery management
}

\author{
Maria M. Criales ${ }^{1, *}$, Laurent Chérubin ${ }^{2}$, Ryan Gandy $^{3}$, Lysel Garavelli ${ }^{4}$, \\ Mohamed Ali Ghannami ${ }^{5}$, Claire Crowley ${ }^{3}$
}

\author{
${ }^{1}$ Rosenstiel School of Marine and Atmospheric Science (RSMAS), University of Miami, 4600 Rickenbacker Causeway, Miami, \\ FL 33149, USA \\ ${ }^{2}$ Harbor Branch Oceanographic Institute, Florida Atlantic University, 5600 US1 N, Fort Pierce, FL 34943, USA \\ ${ }^{3}$ Fish and Wildlife Research Institute (FWRI), 100 Eighth Ave SE, St. Petersburg, FL 33701, USA \\ ${ }^{4}$ Pacific Northwestern National Laboratory, 902 Battelle Blvd, Richland, WA 99354, USA \\ ${ }^{5}$ Ecole Nationale Supérieure des Techniques Avancées Bretagne, 2 rue François Verny, 29806 Brest Cedex 09, France
}

\begin{abstract}
In the Western Atlantic and Gulf of Mexico (GOM), the blue crab Callinectes sapidus fishery is managed at a regional scale, and its assessment does not consider the population structure of the species. To understand connectivity of the blue crab population, we simulated larval dispersal using a biophysical model driven by high-resolution ocean currents and including early life-history traits of the species. Simulations were conducted during 2015 and 2016, and larvae were released from locations along Florida's GOM and Atlantic coasts. A high degree of local larval retention was observed in Florida's GOM waters, mainly during summer when weak southeastern winds tend to yield a shoreward net flow. Results demonstrated clear evidence of connectivity between the Gulf coast of Florida population and those of Mississippi, Alabama, and Louisiana, suggesting that the blue crab populations in the GOM are intermixed and the hypothesized boundary (in Florida) of 2 stocks needs further consideration. Outputs of the model also indicated connectivity between the blue crab populations of Florida's Gulf coast and the South Atlantic Bight (SAB). Larval trajectories showed inter-annual variability driven by the interaction of winds, Loop Current (LC) intrusions in the northern GOM, LC eddies and their cyclonic counterparts, and the Mississippi River plume. The latter provides a conduit for larval transport from the GOM to the SAB. These findings provide evidence of the physical oceanographic processes that sustain the homogenous genetic population structure for blue crabs between SAB and GOM populations, highlighting the need for collaborative management in US waters.
\end{abstract}

KEY WORDS: Larval dispersal $\cdot$ Connectivity $\cdot$ Fishery management $\cdot$ Blue crab

\section{INTRODUCTION}

In the Western Atlantic and Gulf of Mexico (GOM), a well-established fishery exists for the blue crab Callinectes sapidus that is contiguous from Texas to New Jersey (Guillory et al. 2001). The assessment and management of the United States (US) blue crab fishery is regional and delineated by state jurisdic-

*Corresponding author: mcriales@rsmas.miami.edu tions and boundaries. This management structure limits assessments of blue crab to state and regional boundaries that may not align with its natural population structure and distribution across its US range. Florida is no different from other US states in its approach to blue crab management. Within Florida, a single statewide stock structure is assumed for management. However, the assessment of the blue crab

(C) The authors 2019. Open Access under Creative Commons by Attribution Licence. Use, distribution and reproduction are unrestricted. Authors and original publication must be credited. 
stock throughout the Florida peninsula is based on 2 stocks (eastern and western coast) (Cooper et al. 2011), each modeled as a closed population with no exogenous sources of recruits.

In 2011, the Gulf States Marine Fisheries Commission (GSMFC) completed the first Gulf of Mexico Data Assessment and Review (GDAR 01) for blue crab (VanderKooy 2013), and updated the Gulf Regional Management Plan for Blue Crabs (Perry \& VanderKooy 2015). The GDAR 01 was an exercise by the GSMFC to explore the expansion of the assessment of the GOM blue crab stock beyond traditional state boundaries. In this assessment, the GOM blue crab population was separated into 2 stocks: a 'Western Gulf' stock from central Texas to Apalachicola Bay (Florida; centered in Louisiana), and a Florida or 'Eastern Gulf' stock along the west coast of Florida, up to Apalachee Bay (centered in Tampa Bay) (VanderKooy 2013). The geographic feature of Cape San Bass in Florida served as the physical break for stock separation and was justified by (1) findings of an eastern and western blue crab population (Kordos \& Burton 1993), (2) the restricted gene flow in the Western Gulf and a Florida population that did not exhibit population structuring (Darden 2004), (3) a limited number of tagged adult female blue crabs migrating northwest along the Florida coast were found west of Cape San Blass in the Florida panhandle (Steele 1991), (4) larval mixing and migration patterns in the northern GOM (Johnson \& Perry 1999, Perry et al. 2003), and (5) the natural population break for other species, such as red snapper Lutjanus campechanus, near Florida's Apalachee Bay (Johnson et al. 2013). The GDAR 01 successfully assessed the GOM blue crab stocks with a 2-stock structure. However, the accompanying Regional Management Plan recognized that there are shortcomings in the stock delineation used in the model and recommended further study of larval and adult movements as well as genetic studies to support the delineation of stocks in future GDAR assessments.

Following the publication of the GDAR 01 and Regional Management Plan, a population genetic study by Feng et al. (2017) found no population subdivision among samples of adults and larvae from 3 US regions (Northeast, Mid-Atlantic, and GOM). The findings of Feng et al. (2017) support the findings of McMillen-Jackson et al. (1994) and McMillen-Jackson \& Bert (2004), who found no difference in Atlantic and GOM blue crab population genetic structure. However, these authors were unable to support the findings of 2 Gulf populations proposed by Kordos \& Burton (1993) and Darden (2004), or the latitudinal cline proposed by McMillen-Jackson et al. (1994) and McMillen-Jackson \& Bert (2004). The discrepancy in findings may be attributed to the large difference in sample size, and the multiple life stages used to develop markers with greater sensitivity (Feng et al. 2017). These studies showed an overall gene flow throughout the US blue crab population, except those populations near Apalachicola, Florida, which have been found to exhibit a degree of isolation (Darden 2004, Feng et al. 2017). This isolation may be due to their proximity to the Loop Current (LC) (Feng et al. 2017), which could be a prominent larval transport feature in the GOM (Lee et al. 2002, Garavelli et al. 2018). Assessing the connectivity of blue crab larvae along the Florida coast is essential for identifying the population structure of the species.

The blue crab life cycle is complex and begins as planktonic larvae (e.g. Epifanio et al. 1984, 1989). A major influence of abundance in species with planktonic larvae is the degree in which larval dispersal influences recruitment (Scheltema 1986, Cowen \& Sponaugle 2009). Larval dispersal is determined by ocean circulation patterns, the location and timing of spawning, larval behavior, and the duration of the planktonic phase (Pineda et al. 2007). In the GOM, studies on larval dispersal and connectivity of blue crabs are limited to megalopal settlement events linked to wind-driven and tidal circulation processes (Perry et al. 1995, Rabalais et al.1995, Morgan et al. 1996, Hasek \& Rabalais 2001, Spitzer et al. 2003). More recently, seasonal and lunar drivers were also identified as significant factors in the settlement of megalopae in the northern GOM (Grey et al. 2015). No transport mechanisms or connectivity of blue crab populations have been identified in the remaining GOM. Jones et al. (2015) illustrated the utility of oceanographic modeling to elucidate trajectories of blue crab larvae in the northern GOM using an individual-based model. In contrast, blue crab larval transport mechanisms have been studied extensively in the Middle Atlantic Bight (MAB) (e.g. McConaugha et al. 1983, Epifanio et al. 1989, Epifanio 1995, Epifanio \& Garvine 2001, Tilburg et al. 2005, 2007). Research of areas surrounding the Delaware and Chesapeake Bays demonstrated that blue crab larvae are most likely to recruit to their original bay (Tilburg et al. 2007). However, the connectivity in the northern GOM and along both coasts of Florida may be different because nearshore circulation is primarily driven by wind, tidal currents, outflow from the Mississippi River (MR), intrusions of the LC and its periodic eddies, and the influence of the Gulf Stream along Florida's Atlantic Coast (Weisberg et al. 2001, 2005). 
The objective of our study was to investigate larval dispersal pathways and potential connectivity of blue crab populations in the eastern half of the GOM, and along and around the Florida peninsula to the South Atlantic Bight (SAB). Accomplishing this objective improves our understanding of (1) how spawning blue crab populations in Florida contribute to local, regional, and distant populations; (2) how inshore or offshore spawning location affects the distribution and connectivity of the stock; (3) seasonal and inter-annual patterns of connectivity; and (4) the barriers to blue crab larval exchange (e.g. Cape San Blass, Florida).

\section{MATERIALS AND METHODS}

To meet our objectives, we developed a biophysical larval dispersal model for the blue crab in the eastern GOM and the SAB incorporating larval behaviors derived from previous blue crab studies in the MAB. These elements are fundamental for obtaining accurate locations of the sources and sinks of the blue crab larvae around the Florida peninsula. This model is also valuable in delineating potential breaks in the genetic stock structure, which may facilitate the use of more advanced and accurate blue crab stock assessment models.

\subsection{Circulation on the northeastern shelf of the GOM}

The circulation on the northeastern shelf of the GOM is primarily wind-driven (Cochrane \& Kelly 1986, Li et al. 1997, Nowlin et al. 2005), and the local wind is also a major driver of the surface circulation, structure, and transport pathways of the MR plume (Walker et al. 1996, 2005, Schiller et al. 2011). Easterly winds, which are prevalent during autumn, winter, and spring, drive westward surface currents along the northeastern continental shelf. This pattern is frequently disrupted by short-term wind reversals that occur due to the passage of cold fronts, which can reverse the coastal current and promote eastward and southeastward transport (Walker et al. 2005, Schiller et al. 2011). In summer, winds are mostly from the south-southwest, which engenders eastward flowing coastal currents. The local timevarying along-shore currents are strongly correlated with the mesoscale along-shore wind on the northern GOM shelf (Ohlmann \& Niiler 2005).

Approximately $70 \%$ of the MR flow enters the northeastern GOM through the bird-foot delta; the remaining $30 \%$ of the flow is discharged into the GOM by the Atchafalaya River further west (Walker et al. 1994). Mixing and spreading of the MR plume on the shelf is controlled by a variety of factors, including the wind but also the LC system (LCS) and its proximity to the MR plume. The interaction of the LCS with shelf waters in the northeastern GOM has been extensively described (see Schiller et al. 2011 for further references, Schiller \& Kourafalou 2014), and pronounced eddy-driven cross shelf flows have been observed in the vicinity of the MR outflow (Ohlmann et al. 2001). In this region, filaments of low salinity waters can be entrained by the LC or the LC eddies (LCEs) when impinging against the shelf break (Morey et al. 2003, Walker et al. 2005). This increases the likelihood of MR waters to be transported along the edge of the LC, down to the Straits of Florida (Walker et al. 1994, Ortner et al. 1995, Gilbert et al. 1996, Yeung et al. 2000, Hu et al. 2005). Le Hénaff \& Kourafalou (2016) combined the use of numerical simulations and observations to reveal a unique pathway that brings MR waters first eastward along the northeastern GOM continental shelf, under prevailing winds and the presence of an anticyclonic LCE, then southward along the edge of the West Florida Shelf (WFS), before reaching the deep GOM. Once near the Florida Straits, MR waters are advected from the deep ocean onto the continental shelf under the influence of both a LC cyclonic frontal eddy and wind-induced shelf flows.

\subsection{Blue crab life history}

In the northern GOM, female blue crabs spawn in the lower estuaries and rivers (e.g. Steele \& Perry 1990, Gelpi et al. 2009, Flaherty \& Guenther 2011, Crowley et al. 2018). Recent studies have identified aggregations of pre-spawn and ovigerous females 25 to $50 \mathrm{~km}$ from Louisiana's bays (Gelpi et al. 2013) and up to $13 \mathrm{~km}$ offshore along the SAB (Dudley \& Judy 1971, Ogburn \& Habegger 2015). The Southeast Area Monitoring and Assessment Program's (SEAMAP) offshore trawl data has revealed low densities of widely distributed mature and spawning females in the waters offshore in the GOM (VanderKooy 2013) and SAB (Ogburn \& Habegger 2015). A 4 yr Fish and Wildlife Research Institute (FWRI FIM Inhouse Report 2015) study (2014-2017) of the spawning population of blue crab along Florida's coasts revealed bimodal spawning seasons spanning 10 mo (December to September) on the Atlantic coast (Jacksonville and Ormond Beach) and (January to October) on the Gulf coast (Panama 
City) (Crowley et al. 2018). The duration and spawning pattern of Panama City was similar to the findings of Steele \& Bert (1994) for Florida's central Gulf coast (Tampa Bay), whereby a bimodal pattern with a major spring period (January to June) and a minor late summer period (August to November) was observed.

Spawned larvae develop offshore in 7 or 8 zoeal stages, lasting 30 to $50 \mathrm{~d}$, before reaching the megalopa stage that lasts 10 to $15 \mathrm{~d}$ (Costlow \& Bookhout 1959). The pelagic larval duration (PLD) is variable, affected by sea temperature and salinity (Costlow 1967). Zoeae develop on the continental shelf at high salinities (Epifanio et al. 1984). In laboratory conditions, zoeae are unable to complete development to the megalopal stage at salinities below 25 (Costlow \& Bookhout 1959). Megalopae reenter estuaries and settle in nursery habitats containing submerged aquatic vegetation (Perry et al. 2003, Spitzer et al. 2003). Blue crab larvae display distinct patterns of vertical distribution in the water column throughout ontogeny (Epifanio 1988, Biermann et al. 2016). Sulkin et al. (1980) studied the behavior of blue crabs under laboratory conditions and found that early zoeae I occurred high in the water column and late zoeae IV-VII occurred in deeper vertical positions, suggesting a daily vertical migratory (DVM) behavior. However, field observations did not coincide with these findings because zoeae have been found near the surface throughout all development stages (Epifanio et al. 1984, Epifanio 1988, Little \& Epifanio 1991). On the other hand, a DVM behavior for megalopae was observed by Epifanio et al. (1984) and Biermann et al. (2016). Near the estuaries, megalopae perform vertical migrations synchronized with the flood phase of the tide to complete their ontogenetic migrations between oceanic and estuarine habitats, a mechanism known as selective tidal stream transport (STST) (see Forward \& Tankersley 2001 for review). The combinations of behaviors that comprise STST in the blue crab have been described in detail by Forward et al. (2003).

\subsection{Hydrodynamic model}

The Naval Oceanographic Office (NAVOCEANO) operates regional ocean prediction systems based on the Navy Coastal Ocean Model (NCOM; Barron et al. 2006). The Naval Research Laboratory developed NCOM, which is based on the Princeton Ocean Model with time invariant hybrid (sigma over Z) vertical coordinates. In this study, we used the velocity and density fields from NCOM AMSEAS to simulate the transport of blue crab larvae. NCOM AMSEAS is a regional NCOM simulation whose domain covers the Americas Seas region including the GOM and the Caribbean Sea at $1 / 36^{\circ}(\sim 3 \mathrm{~km})$ horizontal resolution and is discretized over 40 levels in the vertical. The model topography comes from the Naval Research Laboratory Digital Bathymetry Data Base 2-minute resolution (NRL DBDB2) digital bathymetry database. The atmospheric forcing fields are provided over this domain by a $15 \mathrm{~km}$ application of the Navy's Coupled Ocean/Atmosphere Mesoscale Prediction System (COAMPS ${ }^{\circledR}$ ) model. The AMSEAS ocean prediction system assimilates all quality-controlled observations in the region including satellite sea surface temperature and altimetry, as well as surface and profile temperature and salinity data using the NRL-developed Navy Coupled Ocean Data Assimilation (NCODA) system. Boundary conditions are applied from the NAVOCEANO operational $1 / 12^{\circ}$ Global HYCOM (Chassignet et al. 2009). The model is forced by tides and discharges from 53 rivers in the region (Ko et al. 2003). NAVOCEANO distributes 3-hourly NetCDF files containing ocean temperature, salinity, eastward and northward currents, and elevation, along with the atmospheric forcing fields. The files are accessible from the National Centers for Environmental Information (NCEI). AMSEAS time aggregated data set is available from 2010 to present.

The AMSEAS model reproduced the oil spill transport in response to the Deepwater Horizon oil spill event with a particular focus on pollution pulses that penetrate into the estuaries east of the MR (Zaron et al. 2015). This model was also used to predict likely drift tracks of sea turtle carcasses in the north central GOM (Nero et al. 2013). In a more recent study, Garavelli et al. (2018) used AMSEAS to simulate coral reef larvae transport within and from the Flower Garden Bank in the northwestern GOM.

\subsection{Biophysical model}

To investigate the larval dispersal patterns and connectivity of blue crab along the coast of Florida and adjacent waters, we developed a biophysical model using the Connectivity Modeling System (CMS; Paris et al. 2013). The CMS is an open-source, multi-scale biophysical model, with Lagrangian tracking based on a $4^{\text {th }}$ order Runga-Kutta integration scheme. For the diffusion coefficient in the Lagrangian model we followed the Okubo scale (Okubo 1971). This coefficient is used to apply a random displacement to each movement component, and its value depends on the 
size of the model grid, in our case $3 \mathrm{~km}$. In the model, each particle represents a larva characterized by its longitude, latitude, and depth. Using hydrodynamic outputs from AMSEAS, particles were tracked at each time step of the model (i.e. $3600 \mathrm{~s}$ in our study). The biophysical model possesses sub-grid turbulence motion and has the flexibility to incorporate both a benthic habitat and a biological module.

Blue crab life history traits were parameterized in the biological module; specifically, the PLD and larval behaviors (ontogenetic vertical migrations and STST behavior). Based on Costlow's (1967) data, 2 PLDs were selected according to the spawning season: a $40 \mathrm{~d}$ PLD ( $30 \mathrm{~d}$ zoea $+10 \mathrm{~d}$ megalopa) for the larvae released during boreal summer/fall months (June to December) and a $55 \mathrm{~d}$ PLD ( $40 \mathrm{~d}$ zoea $+15 \mathrm{~d}$ megalopa) for boreal winter/spring months (January to May). To cover the $55 \mathrm{~d}$ larval dispersal, simulations started in November of the previous year. Vertical distribution data of the blue crab larvae in GOM waters were not available; therefore, larval behavior was parameterized using results from vertically stratified plankton surveys conducted at Chesapeake and Delaware bays (Epifanio et al. 1984, Epifanio 1988, Biermann et al. 2016). Larval vertical distribution patterns observed in the plankton surveys were used to create a vertical matrix $(z, \Delta t)$, in which the probability density distributions in the water column $(z)$ were calculated through time intervals $(\Delta t)$ for each developmental stage (zoea and megalopae) (Table 1). As Table 1 indicates, blue crab larvae perform ontogenetic vertical migration; zoeal stages remain near the surface throughout their development, but later megalopae were found in almost equal percentages, 30 and $35 \%$, near the bottom and at the surface layer respectively. The well documented STST behavior of megalopae while approaching the nearshore estuaries (e.g. Forward \& Tankersley 2001) was simulated in the model for the last $7 \mathrm{~d}$ of dispersal (Day 33 in summer/fall and Day 48 in winter/spring). The CMS uses the sea surface height information included in the hydrodynamic model to reproduce the STST behavior. In our model, megalopae move following the currents when the sea surface height rises (during flood tide) and stop moving when the sea surface height falls (during ebb tide).

The benthic habitat module accounted for blue crab spawning ground locations and suitable habitats for settlement. We used data from different sources to determine the most reliable spawning locations of the blue crab: (1) locations from studies of mature female blue crabs in Florida (Tagatz 1968, Steele \& Bert 1994, Crowley et al. 2018); (2) reports of pre-spawn
Table 1. Matrix table of the vertical distribution of blue crab zoeae and megalopae in the water column representing probabilities (\%) of larval densities at their respective depth strata. Data were derived from stratified plankton studies from Epifanio et al. (1984), Epifanio (1988) and Biermann et al. (2016) at Chesapeake and Delaware Bays. The pelagic larval duration was based on Costlow (1967)

\begin{tabular}{|lcc|}
\hline Depth $(\mathrm{m})$ & $\begin{array}{c}\text { Zoea I-VIII } \\
\text { 30 d (summer) } \\
\text { 40 d (winter) }\end{array}$ & $\begin{array}{c}\text { Megalopae } \\
\text { 10 d (summer) } \\
\text { 15 d (winter) }\end{array}$ \\
\hline Neuston $=0$ & 25 & 35 \\
Surface $=5$ & 57 & 25 \\
Middle $=15$ & 15 & 10 \\
Near bottom $=23$ & 3 & 30 \\
\hline
\end{tabular}

female blue crabs in the literature (e.g. Steele 1991, Perry \& VanderKooy 2015), and (3) locations derived from backward simulations conducted in this study (see Section 3.1). Based on these sources, we selected 11 spawning sites along the west and east coasts of Florida: Panama City (PC), Apalachicola Bay (AaB), Apalachee Bay (AeB), Cedar Key (CK), Tampa Bay (TB), Charlotte Harbor (CH), Whitewater Bay (WB), Card Sound (CS), St. Lucie Inlet (SL), Ormond Beach (OB), and Jacksonville (JX) (see Fig. 1).

Coastal areas with submerged aquatic vegetation, mainly seagrass areas, are considered the primary settlement habitats of blue crab megalopae (e.g. Lipcius et al. 2007). In Florida, juvenile blue crab abundance data from the FWRI Fisheries-Independent Monitoring program aided in the development of the settlement habitat locations (FWRI FIM Inhouse Report 2015). GIS-layer polygons from seagrass, oyster banks, and marshes were used to delineate the benthic habitats in Florida. In addition to the benthic habitats, 1128 settlement polygons $(10 \times 20 \mathrm{~km})$ were created in GIS, grouped in 17 geographical regions including coastal regions of Florida, Alabama, Louisiana, Mississippi, and Georgia (see Fig. 1). This size of habitat polygons $(10 \times 20 \mathrm{~km})$ was very reasonable considering the model's resolution $(3 \mathrm{~km})$, the total number of polygons (1220) and the number of particles released per month (132000). Similar polygon sizes have been used in models of the same resolution (e.g. Sponaugle et al. 2012, Criales et al. 2015).

\subsection{Larval simulations}

The first set of simulations was designed to identify favorable blue crab spawning areas. We performed larval dispersal simulations backward in time, i.e. larvae were released from a settlement area and 
their final location corresponds to their potential release area. We used the locations of blue crab settlement stages from the FWRI FIM program for 2015 derived from $<50 \mathrm{~mm}$ crab catch, which indicates settlement of megalopae in the nearby estuary (FWRI FIM Inhouse Report 2015). We described 6 polygons corresponding to settlement areas: St. George Sound (Apalachicola Bay), Suwanee River Basin (Cedar Key), Charlotte Harbor Bay System (Charlotte Harbor), Tampa Bay, St. John's River (Jacksonville), and Indian River Lagoon (IRL).

The second set of simulations were forward in time and designed to assess blue crab larval connectivity in Florida (via habitat polygons) and regional larval connectivity with neighbor states (via settlement polygons). Three $20 \mathrm{~km}^{2}$ inshore polygons and three $20 \mathrm{~km}^{2}$ offshore polygons were designed at each of the 11 spawning locations identified along Florida's GOM and Atlantic coasts. The release depth of the larvae was set to $5 \mathrm{~m}$ for the polygons located in the GOM and $15 \mathrm{~m}$ on the eastern Florida coast. The different depths at which particles were released resulted from consideration of the different coastal geomorphology and depths between the GOM and eastern Florida coast. The GOM is shallower than the eastern Florida coast, and to maintain the spawning stations at a consistent distance from the coast it was necessary to use different depths. Furthermore, these different depths at spawning coincide with observations from both the Fisheries-Independent Monitoring program (FWRI FIM Inhouse Report 2015) and the FWRI blue crab spawning study (Crowley et al. 2018) that the majority of blue crab spawning occurs in depths of less than $10 \mathrm{~m}$ on the northeastern GOM region and less than $20 \mathrm{~m}$ on the eastern Florida coast.

For both backward and forward simulations, 1000 particles (representing virtual larvae) were released on Days 1, 8, 15, and 22 from the centroids of each polygon separately for onshore and offshore stations. The total number of released particles was $1584000 \mathrm{yr}^{-1}$ (1000 particles polygon ${ }^{-1}$ released 4 times $\mathrm{mo}^{-1}$ ), which is comparable to other studies performed at similar spatial scales (e.g. North et al. 2008, Holstein et al. 2016, Kennedy et al. 2017). The backward simulations were run from March 2015 to November 2015, and the forward simulations for every month of 2015 and 2016.

\subsection{Analysis}

The model simulation outputs were represented as connectivity matrices, $C_{i, j}$. Each value of the connec- tivity matrix described the proportion of virtual larvae released in polygon $i$ that were transported to polygon $j$. Since habitat data were available only for Florida, connectivity data were analyzed separately in 2 matrices: the habitat connectivity matrix, representing outputs of simulations with larvae settling in the Florida habitat polygons, and the regional connectivity matrix, with larvae settling in each settlement polygon independent of the existence of habitat. The separation of these 2 matrices enabled the identification of the region in which each particle ended (with habitat or no habitat) and the connectivity information to assess the exchange among regions.

To determine whether the MR outflow was having an effect on the coastal circulation, the MR transport was calculated across a section at $87^{\circ} \mathrm{W}$ spanning 28 to $30.2^{\circ} \mathrm{N}$, over the first $50 \mathrm{~m}$. Following Schiller et al. (2011), the transport was computed as:

$$
Q_{\mathrm{fw}}=\iint S_{\mathrm{a}} u \mathrm{~d} z \mathrm{~d} y
$$

where $S_{\mathrm{a}}$ is the salinity anomaly relative to the World Ocean Atlas 2013 climatology (Boyer et al. 2013):

$$
S_{\mathrm{a}}=\frac{S_{\mathrm{c}}-S}{S_{\mathrm{c}}}
$$

where $S_{\mathrm{c}}$ is the climatological salinity and $u$ is the horizontal current velocity perpendicular to the crosssection.

\section{RESULTS}

\subsection{Backward simulations for identification of spawning locations}

Backward simulations showed short-distance larval ingress around the GOM settlement areas, contrary to larvae reaching the east coast of Florida (see Fig. S1 in the Supplement at www.int-res.com/articles/suppl/ m625p053_supp.pdf). For the latter, virtual larvae that settled on the east coast of Florida originated in the deep GOM and occasionally from the coast of Louisiana. Trajectories were strongly associated with the LCS system and its eddies, which include both anticyclonic and cyclonic frontal eddies. Furthermore, some of the trajectories of ingressing virtual larvae originated from areas whose distance from shore fell within the inshore and offshore spawning areas used in the forward simulations. This was the case for larvae egressing from AeB (dark blue and yellow trajectories in Fig. S1) and from CS (light blue and red trajectories in Fig. S1), which have both been reported 
in the literature with a high presence of mature and pre-spawned blue crab females (Steele 1991, Steele \& Bert 1994, VanderKooy 2013, Perry \& VanderKooy 2015). Therefore, both sites were added as spawning locations in the forward simulations. From the rest of the backward trajectories, we were also able to confirm previously known spawning aggregation sites such as $\mathrm{TB}$ and $\mathrm{CH}$ (magenta and green trajectories in Fig. S1), and SL and $\mathrm{OB}$ (red and light blue trajectories in Fig. S1) on the east coast of Florida (Fig. 1).

\subsection{Trajectories of forward simulations}

The monthly trajectories of virtual larvae released at inshore and offshore locations showed similar

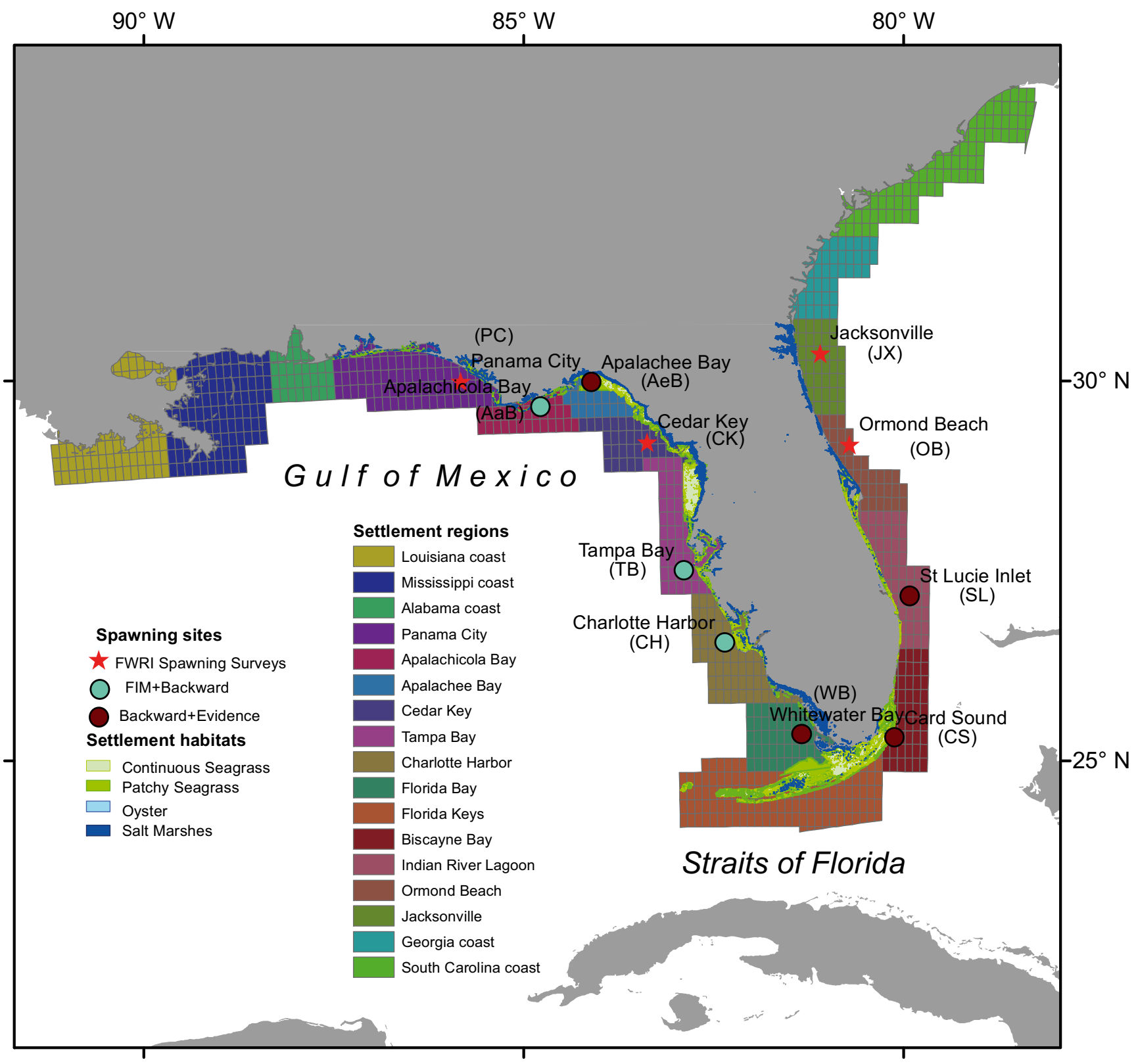

Fig. 1. Study area, depicting blue crab spawning locations, settlement habitats, and settlement polygons grouped in 17 geographical regions from Louisiana (northeastern Gulf of Mexico) to South Carolina (Eastern Atlantic coast). FIM+Backward: spawning locations identified by the Fish and Wildlife Research Institute (FWRI) and Fisheries-Independent Monitoring (FIM) Program surveys and those confirmed by the backward simulations; Backward+Evidence: spawning locations identified from literature evidences of the presence of mature and pre-spawned blue crab females and those confirmed by backward trajectories 
a

February 2015

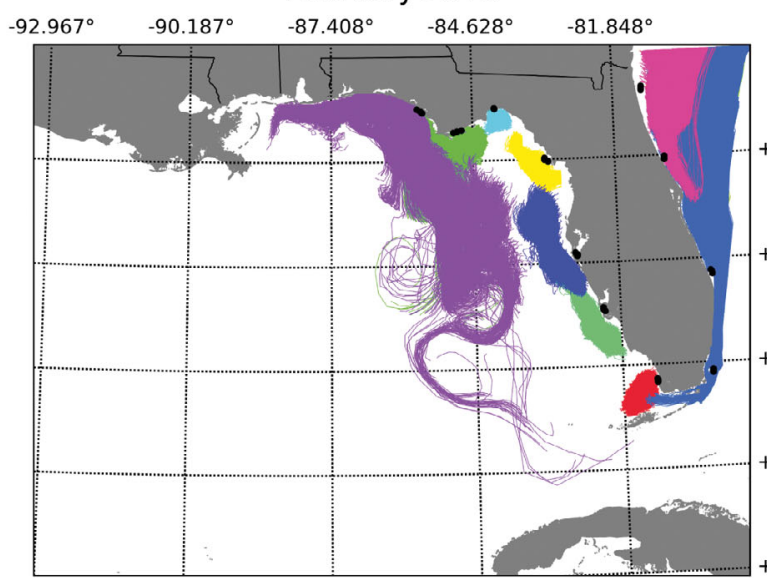

$+22.032^{\circ}$

March 2015
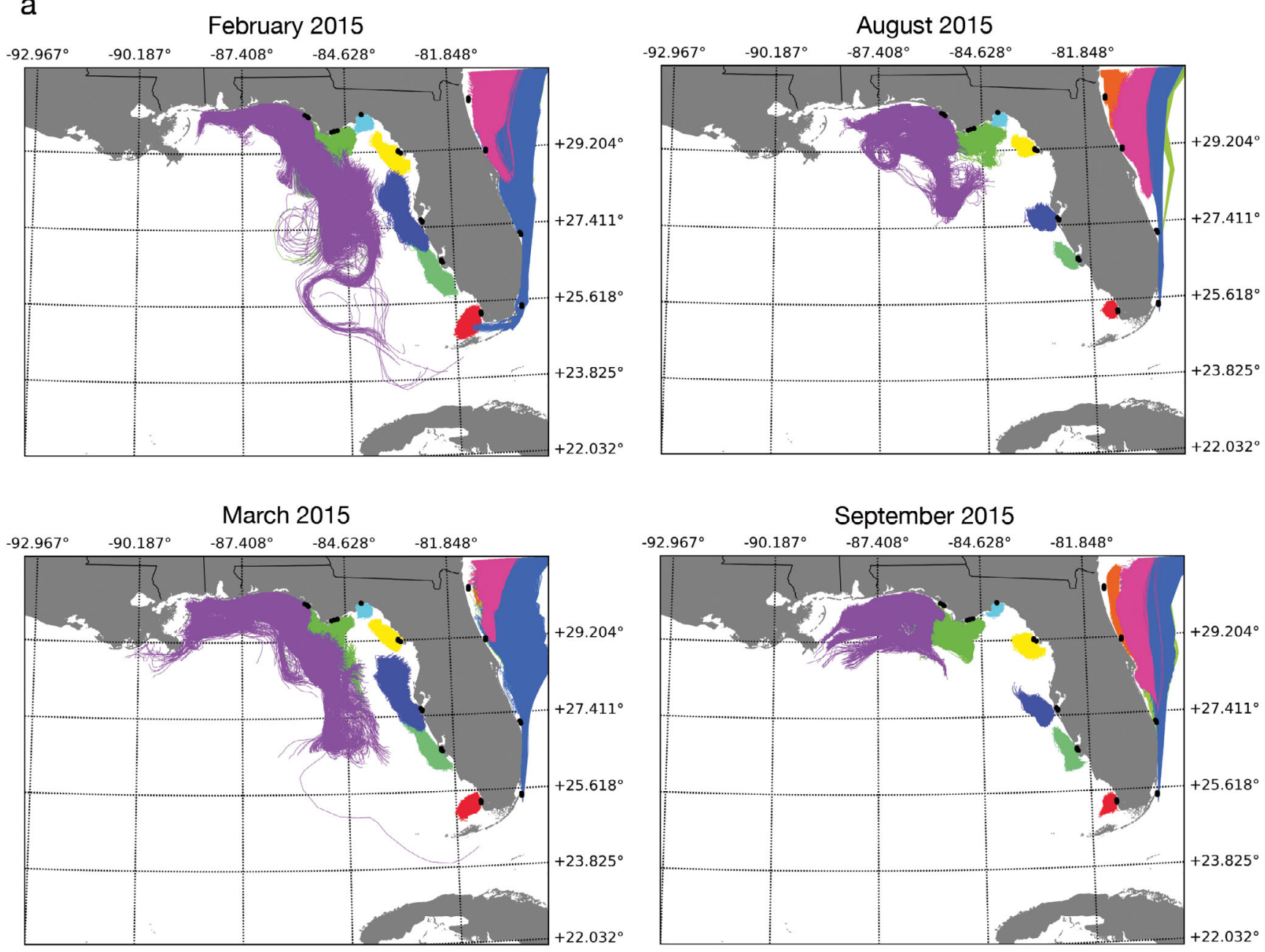
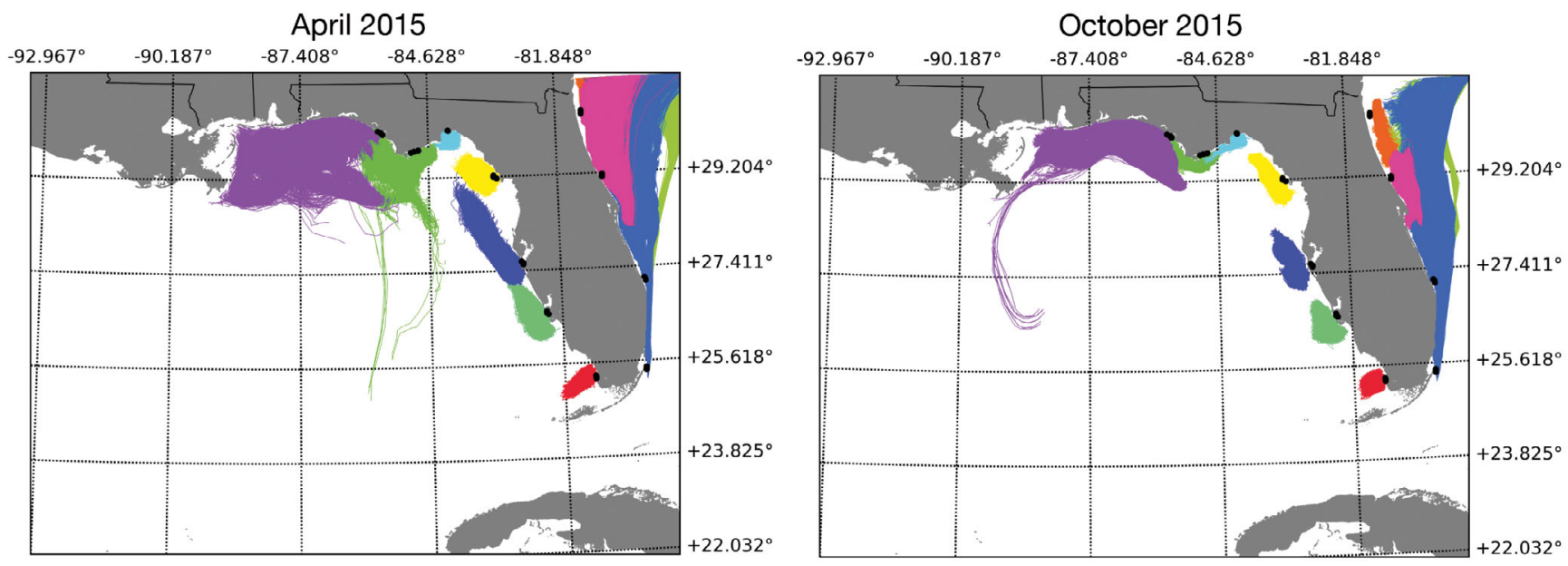

(Fig. 2 continues on next page)

Fig. 2. Trajectories of blue crab larvae from offshore spawning sites derived from forward simulations in (a) 2015 and (b) 2016 for the months of February, March, April, August, September, and October. Each graph depicts the trajectories of the corresponding release month. The trajectories end after 55 (40) d for virtual larvae released in boreal winter (summer). Trajectories at each site are represented by different colors: purple: Panama City; green: Apalachicola Bay; light blue: Apalachee Bay; yellow: Cedar Key; dark blue: Tampa Bay; green: Charlotte Harbor; red: Whitewater Bay; blue: Card Sound; light green:

St. Lucie Inlet; orange: Ormond Beach; and pink: Jacksonville 
b

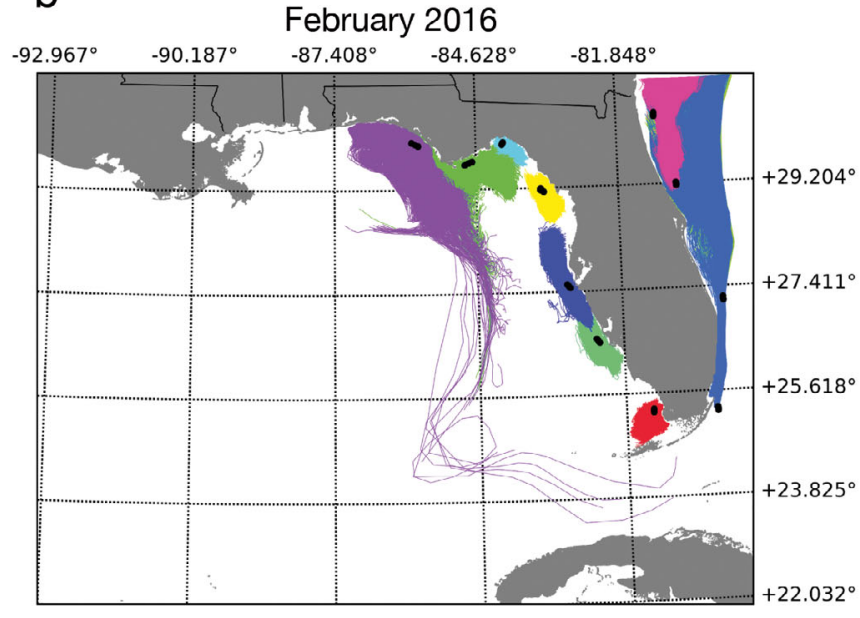

March 2016

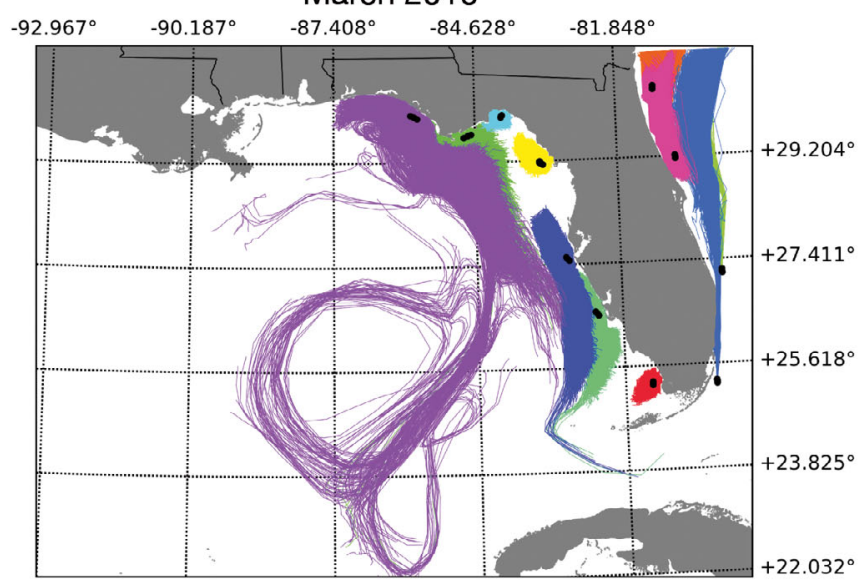

April 2016

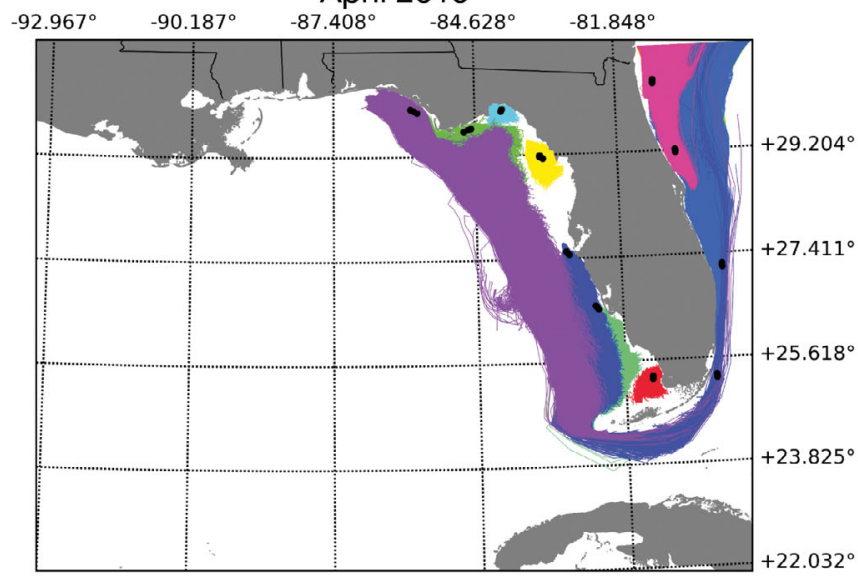

trends, the main difference being that offshore virtual larvae dispersed farther with more intermixing among locations (Fig. 2) than the inshore virtual larvae (Fig. S2). The trajectories of larvae released at the GOM inshore stations in 2015 and 2016 revealed that most virtual larvae were locally retained and
August 2016
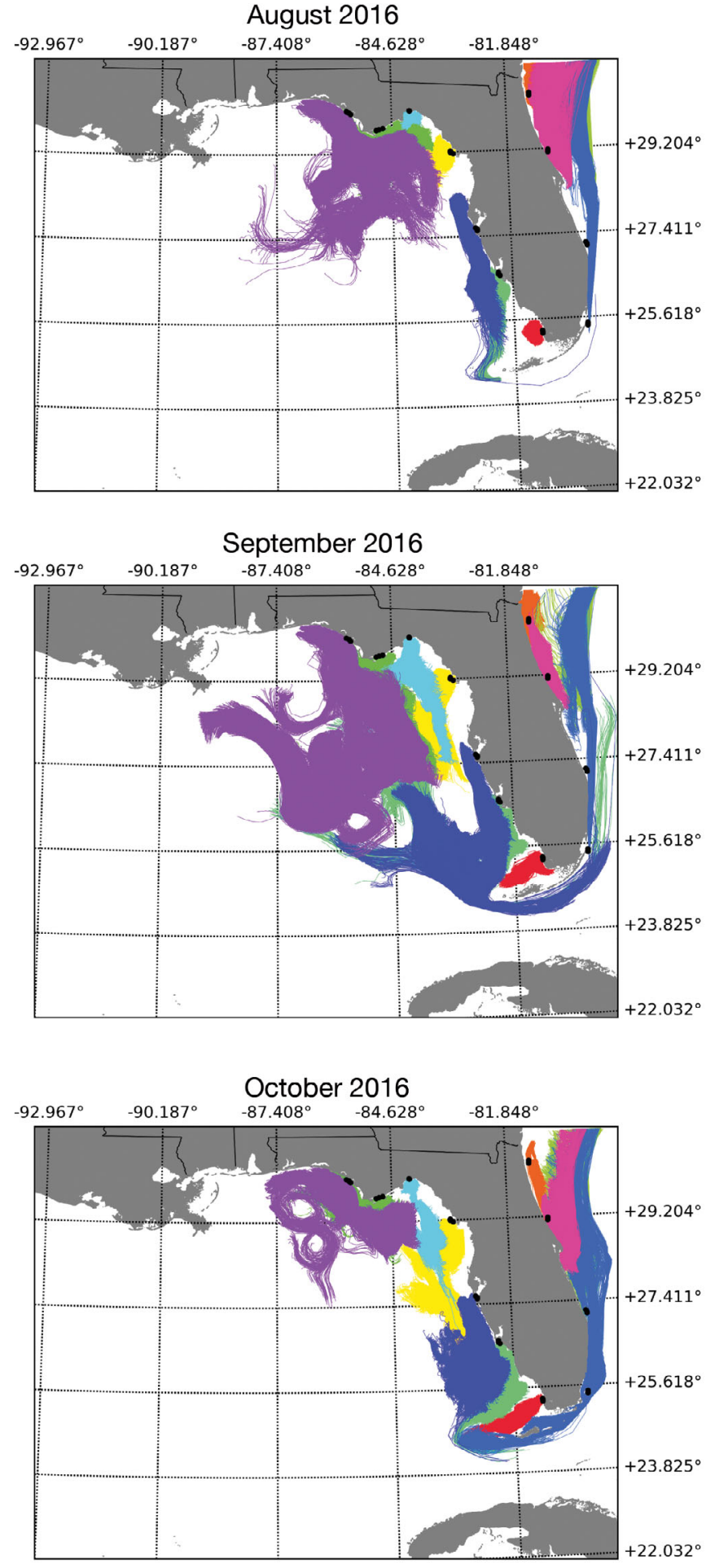

exchanged with neighboring locations on either side of a release location, except at the PC location. At PC, in 2015 larvae dispersed mainly westward along the northern GOM to the Louisiana coast, and in 2016 dispersal was mostly to the south-southeast over the WFS. 
Virtual larvae released at the offshore PC location in 2015 dispersed both west along the northern GOM coast to the Louisiana coast (Fig. 2a) and southsoutheast on the WFS and in the deep GOM, mostly in the winter months. Virtual larvae originating from TB during winter months (February, March, and April 2015) moved north (Fig. 2a), mixing with larvae from the northern GOM locations. In 2016 there was less westward transport compared to 2015, but the south-southeast transport was substantial and contributed to distribution from the GOM towards the SAB. In April 2016, virtual larvae from PC drifted around the peninsula, reaching the east coast (Fig. 2b). In April, September, and October 2016, virtual larvae originating from TB and CH drifted southeast around the Florida peninsula and reached the east coast of Florida. In September and October 2016, virtual larvae originating from $\mathrm{AeB}$ and $\mathrm{CK}$ reached $\mathrm{TB}$ and $\mathrm{CH}$.

Virtual larvae released from inshore and offshore locations on Florida's east coast moved mainly northward into the SAB via the Florida Current, reaching the Georgia coast. However, virtual larvae released from $\mathrm{OB}$ and SL also moved south during summer and winter months of both years, but rarely beyond the south end of the East Florida Shelf (Fig. 2a,b). Virtual larvae released from CS moved south and west into the GOM in February 2015 and October 2016 (Fig. 2a,b).

\subsection{Larval connectivity within Florida}

Connectivity matrices for offshore and inshore release locations demonstrated similar temporal larval settlement patterns; however, in several cases the offshore release locations connected to a more distant settlement habitat than the inshore release locations (Figs. 3a \& S3a). Few differences in settlement patterns were noted between winter and summer, although summer 2015 exhibited the least connectivity in our simulation. Local retention was observed in both years for winter and summer releases at all locations; interestingly, at similar levels for some locations such as AeB, CK, CH, OB, and JX. Along Florida's GOM coast, in both years and all seasons, mixing of larvae occurs among proximal locations in the northwest $(\mathrm{PC}, \mathrm{AaB}, \mathrm{AeB}, \mathrm{CK})$, central west $(\mathrm{CK}$, $\mathrm{TB}, \mathrm{CH})$, and southwest $(\mathrm{CH}, \mathrm{WB})$. Some of these locations made long-range contributions to distant settlement habitat along Florida's west, southwest, and southeast coasts: PC contributed to the Florida Keys and Biscayne Bay; AaB contributed to the
Florida Keys; and TB and CH contributed to Florida Bay, the Florida Keys, and Biscayne Bay. Near the southwestern tip of the Florida peninsula, virtual larvae released at WB settled north in $\mathrm{CH}$, to the east in the Florida Keys, Florida Bay, and Biscayne Bay very consistently.

Virtual larvae released from CS moved south to the Florida Keys, southwest to Florida Bay, or north, settling at locations on Florida's Atlantic coast (IRL, OB, and JX). Virtual larvae released from 3 other of Florida's Atlantic coast locations (SL, OB, JX) generally contributed larvae to each of the Florida locations to the north of the release location all the way to Georgia's coast. However, some larvae moved south along the coast, against the dominant flow; OB contributed consistently to the IRL, and JX contributed to OB.

\subsection{Regional connectivity}

Regional connectivity matrices for offshore and inshore release locations showed local retention and temporal variability in larval settlement. In some cases, offshore release locations connected to more distant regions than inshore release locations (Figs. 3b \& S3b). In 2015, larvae released at the offshore stations during winter and spring months tended to disperse further, while virtual larvae released during summer months showed a more pronounced retention - contrary to 2016, when summer transport was more significant than in winter (Figs. 2b \& 3b). Three locations on the GOM coast (PC, $\mathrm{AaB}$, and $\mathrm{TB}$ ), and 4 locations on the Atlantic coast (CS, SL, OB, and JX) made consistent long-range connections. During winter 2015, virtual larvae released from the PC location settled mostly across the entire northeastern GOM region (Louisiana, Mississippi, Alabama, PC, $\mathrm{AaB}, \mathrm{AeB}, \mathrm{CK}$, and connected to Florida Bay) and

Fig. 3. (a) Habitat connectivity and (b) regional connectivity matrices showing the number of blue crab larvae transiting between each release ( $y$-axis) and settlement ( $x$-axis) habitats from offshore locations in 2015 and 2016 boreal winter and boreal summer months. Boreal winter (summer) virtual settlements periods correspond to January to May (June to December), respectively. Color bar ( $\log _{10}$ scale): number of larvae. Settlement and release locations used in the matrix are labeled according to their longitude. The South Carolina settlement region was left out of the connectivity matrices because no larvae reached that region in our simulations. The Louisiana, Mississippi and Alabama coastal regions were not included in the habitat connectivity matrices because no larvae settled in these regions 
a

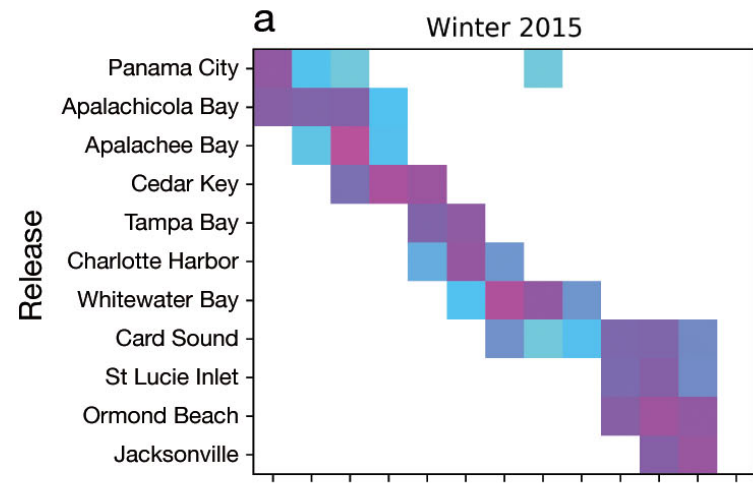

Summer 2015
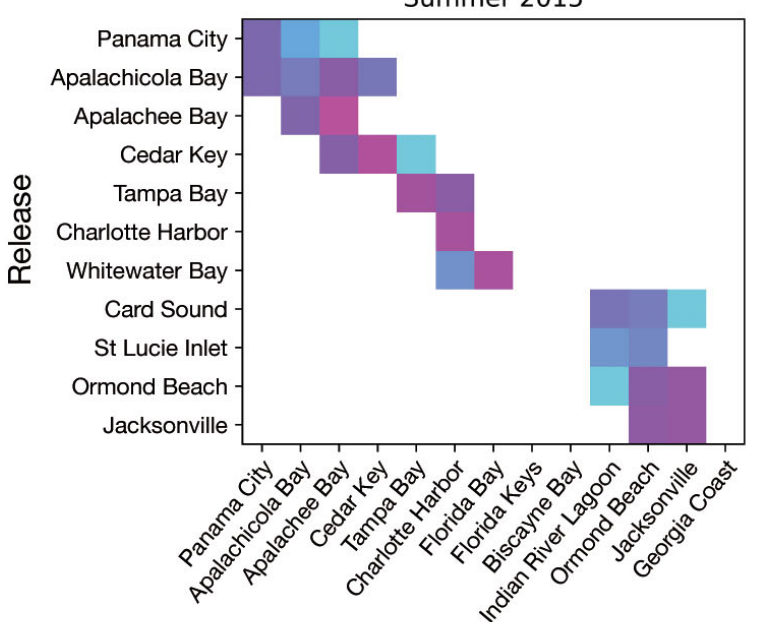

Settlement
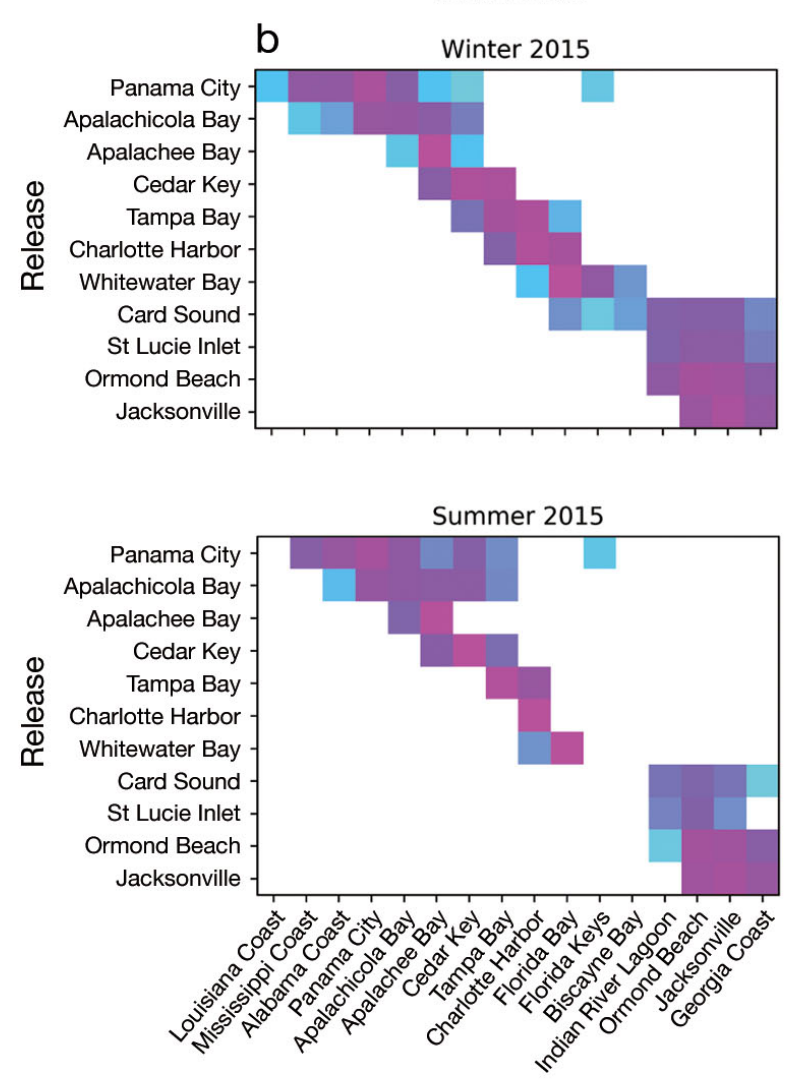

Settlement
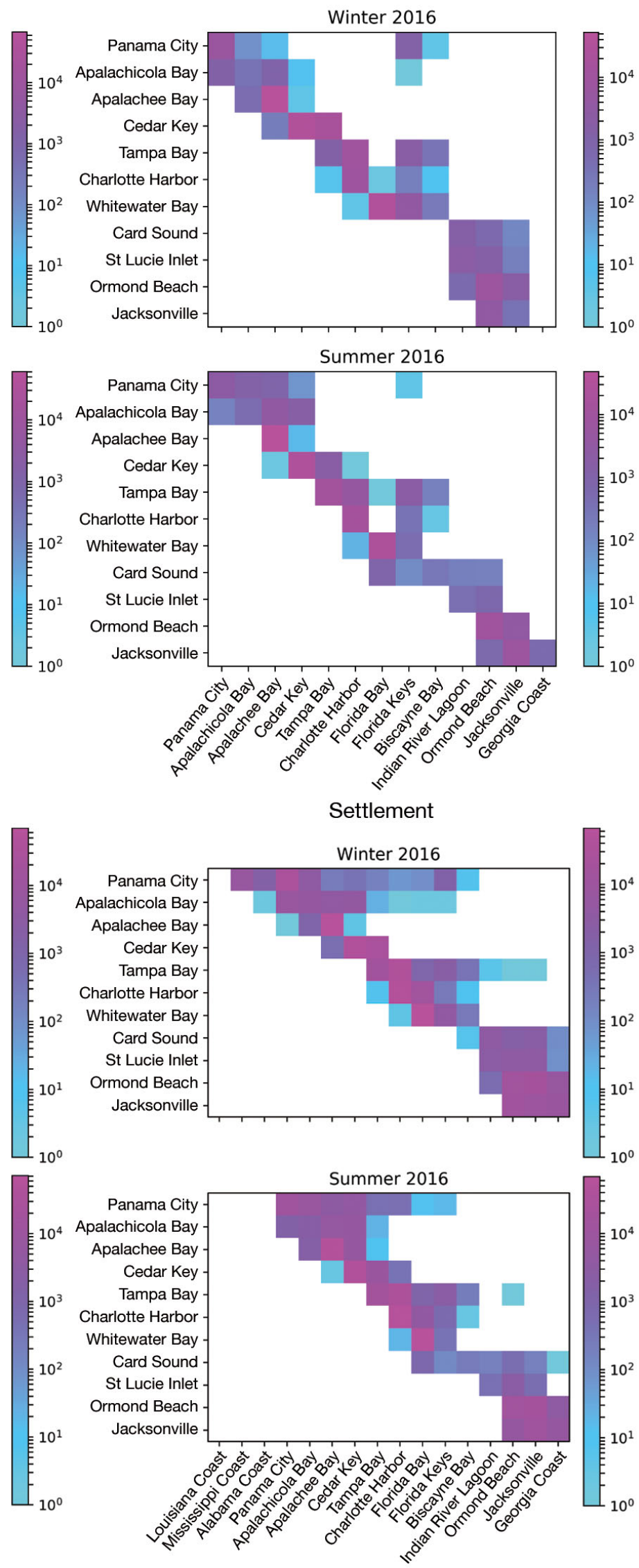

Settlement 
during summer 2015, virtual larvae settled at the same locations except Louisiana (Fig. 3b). Released from PC in the summer of 2016, virtual larvae settled across the entire eastern GOM region including $\mathrm{PC}$, $\mathrm{AaB}, \mathrm{Aeb}, \mathrm{CK}, \mathrm{TB}, \mathrm{CH}$, and connected to Florida Bay and the Florida Keys. In winter 2016, virtual larvae settled across the entire northeastern and eastern GOM regions (Louisiana, Mississippi, Alabama, PC, $\mathrm{AaB}, \mathrm{AeB}, \mathrm{CK}, \mathrm{TB}, \mathrm{CH}$ ) and connected to Florida Bay, the Florida Keys, and Biscayne Bay on the east coast of Florida (Fig. 3b). Virtual larvae released from AaB in the winter of 2015 connected to locations in northwest and central west Florida $(\mathrm{AeB}, \mathrm{AaB}, \mathrm{PC}$, and $\mathrm{CK}$ ), and to locations along the northern GOM (Mississippi and Alabama) (Fig. 3b). In the winter of 2016, AaB connected with TB, CH, Florida Bay, and the Florida Keys but not with Mississippi (Fig. 3b). Releases from TB in winter 2016 connected south, to Florida Bay and the Florida Keys, and with the Atlantic coast of Florida (Biscayne Bay, IRL, OB, and JX). In summer 2016, TB connected with the same winter locations except Biscayne Bay and OB (Fig. 3b).

During winter and summer of 2015 and 2016, larvae that originated at the 4 inshore and offshore locations along the east coast of Florida (CS, SL, OB, and JX) consistently settled at locations north of their origin, and all contributed larvae to the Georgia coast except SL (Figs. 3b \& S3b). Larvae released from CS in winter 2015 and summer 2016 also reached Florida Bay, the Florida Keys, and Biscayne Bay (Figs. 2b \& 3b).

\subsection{Dynamical state of the eastern GOM during the virtual experiments}

Blue crab larvae trajectories showed differences between 2015 and 2016 (Figs. 2 \& 3). These differences were primarily on the northeastern GOM shelf (north of $29.5^{\circ} \mathrm{N}$ ), between Florida and Louisiana, and along the southern WFS during the winter and spring months. Along-shore wind interannual variability could explain the difference in the westward transport in winter and spring months. However, both years exhibited recurrent easterly wind periods from March to June (Fig. 4a,b), which were even more prolonged in summer 2016 (Fig. 4b), while westward flow was strongly reduced (Fig. 4d). This result suggests that the wind alone is not the major driver of this interannual variability.

Analysis of surface salinity in the eastern GOM in 2015 and 2016 revealed the significant presence of MR water in both years. However, its spatial distribu- tion differed due to opposite freshwater transport direction (Fig. 5), and a different LCS state between both years (Fig. 6). In June 2015, the LC was extended northward into the GOM and interacted with the MR plume by entraining MR waters along the LC front ( $>0$ freshwater fluxes in boreal spring) (Fig. 5a) and into its frontal eddies (Fig. 6a), which led to the entrainment of larvae released near PC into the deep GOM (Fig. 2). However, sustained westward current on the northeastern GOM shelf during the boreal spring (Fig. 4c) prevented MR waters from being transported eastward toward the WFS. Instead, in 2016, the LC shed an eddy (the LCE), which was associated with a cyclonic frontal eddy on the northern side of the LCE (Fig. 6b). The cyclone engendered sustained westward current between 28 and $29.5^{\circ} \mathrm{N}$ (Fig. 4d), hence, westward transport of freshwater shown by negative fluxes during the boreal spring (Fig. 5b). While some larvae were entrained in the cyclonic eddy, some were entrained between the separated LCE and the cyclonic circulation between the LCE to the north and the LC, in a port-to-port configuration to the south (Figs. 2 \& 6b). Enhanced eastward costal current in the northeastern GOM (Fig. 4d) led to a significant eastward transport of MR water on the WSF (Fig. 6b), similar to the event described by Le Hénaff \& Kourafalou (2016). MR waters were then advected southward on the WFS (Fig. 6b) into the Straits of Florida, providing opportunities for connectivity between the northeastern GOM and the east Florida shelf (Fig. 2).

In fall 2015, larvae were entrained in the LCS along with the MR waters (Fig. 2a). This entrainment led to the export of larvae released near PC into the deep GOM between the LCE to the north, and the LC to the south (Fig. 6c). In Fall 2016, larvae were transported south on the WFS but also westward near the northeastern GOM and the southern tip of the WFS (Fig. 2b). This entrainment is the consequence of the absence of the LC in the northern Gulf, which is populated by cyclonic eddies. These eddies tend to advect the MR waters westward (Fig. 6d), as well as larvae released from the west coast of Florida (Fig. 2b).

\section{DISCUSSION}

Successful management of the blue crab fishery is dependent on understanding the complex population dynamics and larval connectivity of the species (Cowen et al. 2006, Botsford et al. 2009). In this study, we developed a high-resolution multi-scale biophysical model, parameterized with blue crab PLD, larval be- 

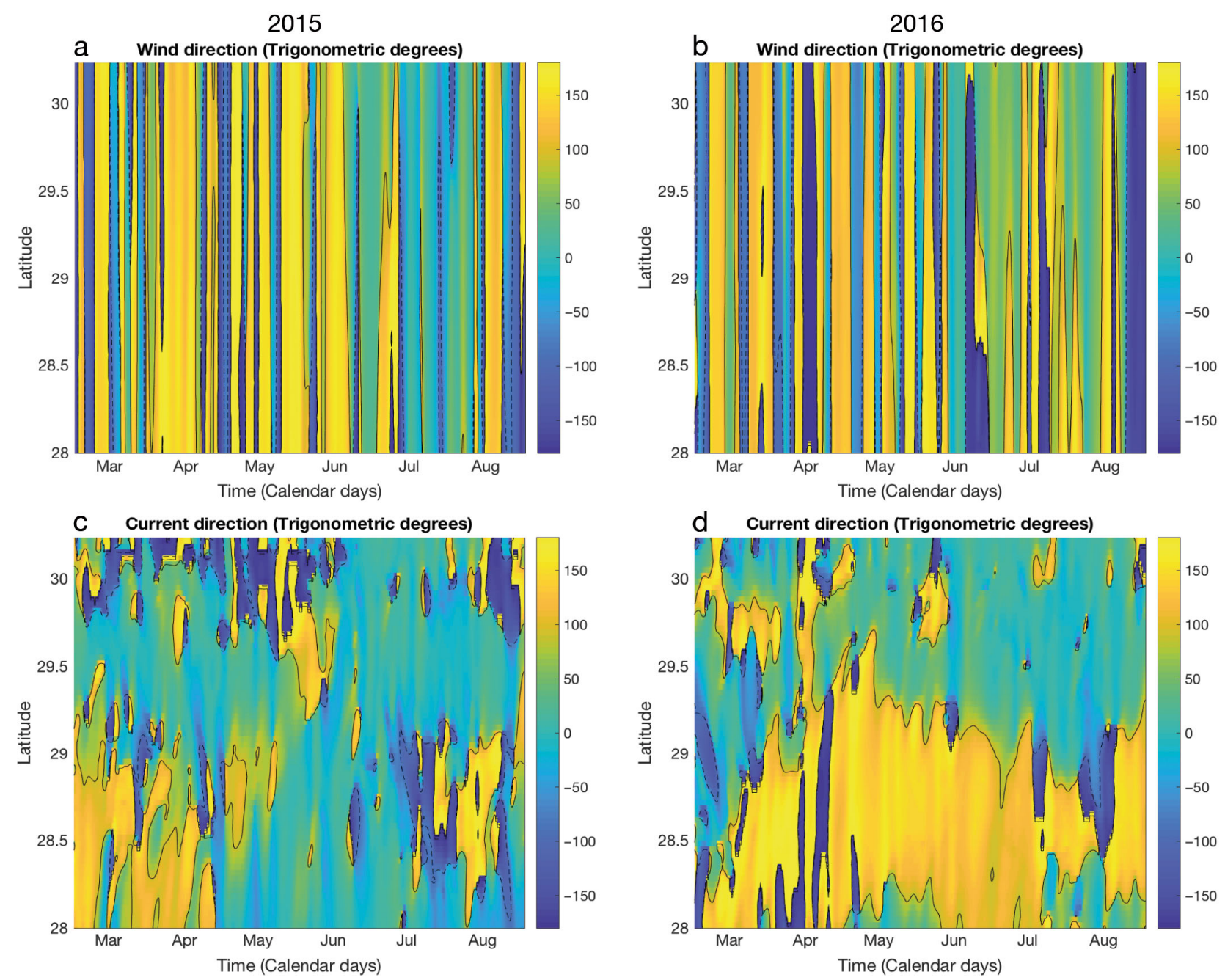

Fig. 4. Hovmüller diagram between 28 and $30.2^{\circ} \mathrm{N}$ at $87^{\circ} \mathrm{W}$ for the period March to August in (a,c) 2015 and (b,d) 2016 ; (a) and (b) represent the model wind direction and (c) and (d) the current direction, respectively. The trigonometric angle convention used in these diagrams indicates where the wind is blowing. Solid (dashed) contours show the $90^{\circ}\left(-90^{\circ}\right)$ angle, namely the north (south) direction; east (west) is indicated by $0^{\circ}\left( \pm 180^{\circ}\right)$

havior, and new data on the spatial distribution of juveniles, habitat settlement, and the spawning seasonality and locations in Florida. The model suggests (1) a high degree of local retention on the Florida coast of the GOM, (2) population connectivity between the west coast of Florida and the neighboring Gulf states of Mississippi, Alabama and Louisiana, and the Florida east coast, and (3) population connectivity between the east coast of Florida, and Georgia coast.

Results from the biophysical model showed high larval retention at the inshore GOM stations mainly during the boreal summer months. In contrast, larvae released at the offshore stations were more widely dispersed during boreal winter and spring months. Larval dispersal also showed variations between the $2 \mathrm{yr}$ due to the difference in mesoscale winds along the northern part of the GOM, and the state of the LCS. The wind direction and intensity appear to control the eastward export of MR waters toward the WFS (Le Hénaff et al. 2012, Le Hénaff \& Kourafalou 2016), while the LCS seems to control the deep-water export of coastal waters (Schiller \& Kourafalou 2014). While an extended LC can provide a pathway from MR waters to reach the Straits of Florida along its front, LC frontal cyclonic eddy and cyclonic eddy turbulence, created by the absence of LC in the northeastern GOM, seem to favor cross-shore export of coastal waters (Schiller et al. 2011). In consequence, offshore larvae released near Cape San Blass appear to be under both the influence of the LCS and the coastal circulation. From the 2 yr larval simulations, larvae offshore of the Cape appear to be the most 


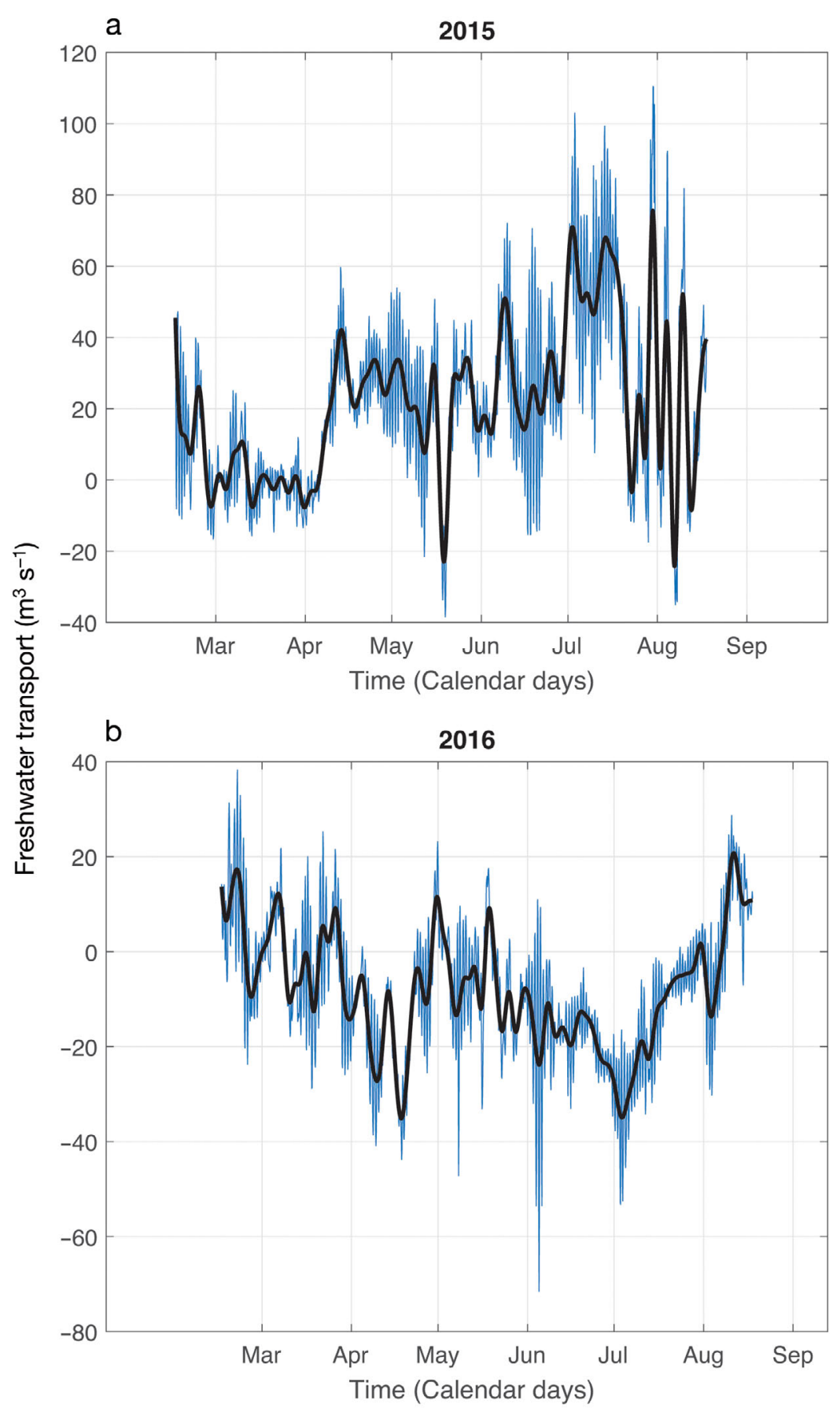

Fig. 5. Model freshwater transport $\left(\mathrm{m}^{3} \mathrm{~s}^{-1}\right)$ time series of the Mississippi River across section at $87^{\circ} \mathrm{W}$ spanning 28 to $30.2^{\circ} \mathrm{N}$, over the first $50 \mathrm{~m}$ in (a) 2015 and (b) 2016. Thin blue line: 3-hourly data; black line: daily variations

winds are sustained and from the southwest quadrant (Fig. 6b), MR waters can be exported to the WFS (Le Hénaff \& Kourafalou 2016). Such export seems to enhance larval transport from all spawning locations on the WFS, increasing the probability of export toward the east coast of Florida.

These findings also provide evidence of the physical mechanisms of connectivity that supports the homogenous genetic population structure for blue crabs among Mid-Atlantic and GOM populations (McMillen-Jackson et al. 1994, Feng et al. 2017). Pockets of genetic heterogeneity found in previous studies (Kordos \& Burton 1993, Darden 2004) near Apalachicola and other Gulf locations are likely explained by the episodic isolation of the population. However, these isolations are periodically overridden by long-distance larval transport of individuals with high genetic diversity and supports the panmictic structure of blue crab populations across the GOM and Western Atlantic (Feng et al. 2017). Genetic studies and larval dispersal pathways only provide insight into the connectivity and mechanisms of connectivity that facilitate natural populations. Further integration of population dynamics (i.e. growth, survival, reproduction) are required to estimate the impact of dispersal on the demographic structure of the population (Lowe \& Allendorf 2010). The totality of genetic and dispersal evidence for the connectivity of blue crab populations across the GOM and SAB suggests that the range-wide physical and genetic connections must be further defined. Once defined, an assessment that integrates immigration and emigration

susceptible to offshore export, with limited chance of recruitment nearshore. This transport feature, in association with a separated LC or the absence of LC, could constitute, near Cape San Blass, a bio-oceanographic filter to larval dispersal between the northeastern and northwestern GOM. When the LC is present and extended to the north, and if mesoscale rates across currently defined borders can be used to adequately represent the structure of the population and form the basis for a regional fishery management strategy of blue crabs in the US.

Our model was purposefully designed to consider only Florida sources of larvae and does not consider exogenous larval sources. This constraint was chosen 

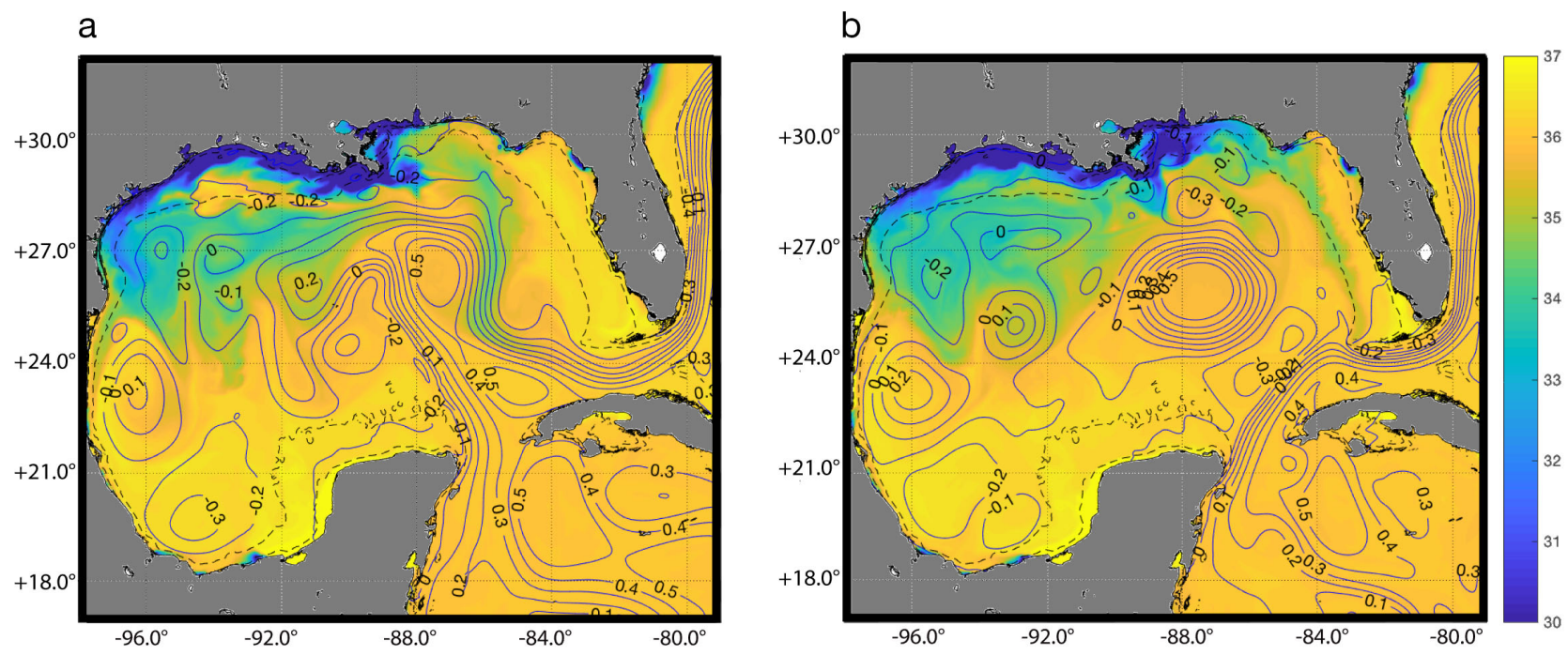

\section{C}

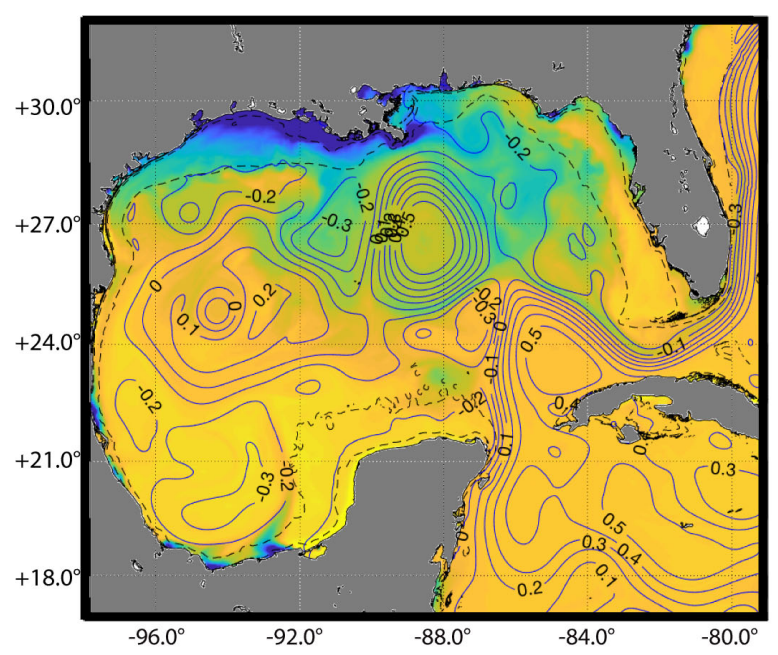

d

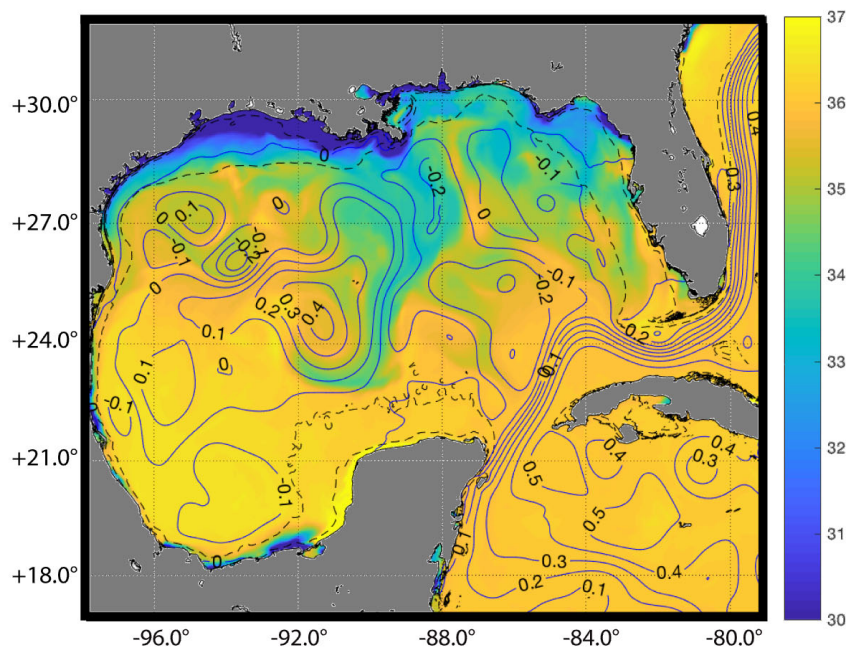

Fig. 6. Modeled first week average of surface salinity (psu) overlaid with sea surface height (SSH) contours (m) in (a) June 2015, (b) June 2016, (c) September 2015, and (d) September 2016. Negative (positive) SSH indicate cyclonic (anticyclonic) eddies

to investigate the utility of the state-centric assessment method and the hypothesized population break at Cape San Blass, Florida, in the northeastern GOM. This population break was specifically used in the GDAR 01 assessment, when establishing blue crab stock population boundaries. That first effort to assess blue crab on a large spatial scale used a 2-stock structure: a western Gulf stock from central Texas to Apalachicola Bay, and an eastern Gulf stock from Apalachicola Bay along the Florida Gulf coast (VanderKooy 2013). Population genetic studies (Kordos \& Burton 1993, Darden 2004), migration patterns of adult female crabs (Steele 1991), and studies of population breaks in other marine populations (Johnson et al. 2009, 2013) were used as justification of the stock separation at Cape San Blass, Florida. Our study suggests that the choice to separate the stock at Apalachicola Bay may be arbitrary because of the exchange of larvae across Cape San Blass to the neighboring states in the northeastern GOM.

Our model was constrained by not including biological factors that are known to influence larval connectivity such as egg production, larval growth, and larval mortality (Pineda et al. 2007). These constraints were used to isolate and quantify the influence of circulation, larval behavior, and habitat location on the dispersal of larvae and on their encounter with suitable settlement habitat. The biophysical model provides predictions of the pre-settlement distribution of larvae, but it does not account for post-settlement processes such as predation and competition, which will reduce the recruitment success of dispersal con- 
nections (e.g. Hunt \& Scheibling 1997, Doherty et al. 2004). While this study found transport of larvae from Florida to neighboring Gulf states and the Western Atlantic, it did not investigate the complete potential for exchange of larvae among those regions. Further investigation into the population structure of blue crabs in the GOM and Western Atlantic should consider using long-term monitoring data sets to inform models. A comprehensive study of hydrologic data, particle motions, genetic data sets (Feng et al. 2017), and correction for natural mortality and habitat suitability would also aid the understanding of the dynamics involved.

In summary, this study is a step towards identifying broader stock connectivity of the blue crab throughout its US range and seeks to encourage more comprehensive approaches that will elucidate the population dynamics of this species. These findings strengthen the evidence for connectivity of the GOM and Western Atlantic blue crabs and emphasize the need to account for this process in the assessment and management of the stock, potentially as a single stock, that relies on distant spawning events. The totality of these findings calls into question the appropriateness of the current state-by-state structure of assessment and highlights a need for cooperative assessment and management of the blue crab in US waters.

Acknowledgements. The authors thank the personnel from the Florida FWRI Fisheries-Independent Monitoring program for providing data for the locations of the settlement habitats, the FWRI GIS personnel for providing the settlement data polygons, the GIS personnel at the Rosenstiel School of Marine and Atmospheric Science, University of Miami for technical assistance and the Responsible Editor and 2 anonymous reviewers for their valuable comments. This work was funded by the Interjurisdictional Fisheries Management Act through the Department of Commerce (NA13NMF4070225) and by the state of Florida.

\section{LITERATURE CITED}

Barron CN, Kara A, Martin P, Rhodes R, Smedstad L (2006) Formulation, implementation and examination of vertical coordinate choices in the Global Navy Coastal Ocean Model (NCOM). Ocean Model 11:347-375

Biermann JL, North E, Boicourt W (2016) The distribution of blue crab (Callinectes sapidus) megalopae at the mouths of Chesapeake and Delaware Bays: implications for larval ingress. Estuar Coast 39:201-217

Botsford LW, Brumbaugh DR, Grimes C, Kellner JB and others (2009) Connectivity, sustainability, and yield: bridging the gap between conventional fisheries management and marine protected areas. Rev Fish Biol Fish 19:69-95

Boyer TP, Antonov JI, Baranova OK, Coleman C and others (2013) World ocean database 2013. NOAA Atlas NESDIS
72. NOAA, Silver Spring, MD. doi:10.7289/V5NZ85MT

* Chassignet EP, Hurlburt HE, Metzger EJ, Smedstad OM and others (2009) US GODE: global ocean prediction with the HYbrid Coordinate Ocean Model (HYCOM). Oceanography (Wash DC) 22:64-75

Cochrane JD, Kelly FJ (1986) Low frequency circulation on the Texas Louisiana continental shelf. J Geophys Res 91: 10645-10659

Cooper W, Gandy RL, Crowley CE (2011) A stock assessment for the blue crab, Callinectes sapidus, in Florida waters through 2011. Publication IHR 2011. Florida Fish and Wildlife Conservation Commission, Fish and Wildlife Research Institute (FWC/FWRI), St. Petersburg, Florida

Costlow JD (1967) The effect of salinity and temperature on survival and metamorphosis of megalops of the blue crab Callinectes sapidus. Helgol Wiss Meeresunters 15:84-97

Costlow JD, Bookhout CG (1959) The larval development of Callinectes sapidus Rathbun reared in the laboratory. Biol Bull (Woods Hole) 116:373-396

Cowen RK, Sponaugle S (2009) Larval dispersal and marine population connectivity. Annu Rev Mar Sci 1:443-466

Cowen RK, Paris CB, Srinivasan A (2006) Scaling of connectivity in marine populations. Science 311:522-527

Criales MM, Cherubin LA, Browder JA (2015) Modeling larval transport and settlement of the pink shrimp in south Florida: dynamics of behavior and tides. Mar Coast Fish $7: 148-176$

Crowley CE, Gandy RL, Walters E, Black T, Hart H (2018) Population surveys of spawning blue crabs resulting in the development of larval dispersal models for the Florida coastal waters and the development of a horseshoe crab citizen scientist program. Final Performance Report to the National Marine Fisheries Service: NA13NMF4070225. St. Petersburg, Florida. Florida Fish and Wildlife Conservation Commission, Fish and Wildlife Research Institute. Report No F4139-13-F. https:// f50006a.eos-intl.net/F50006A/OPAC/Details/Record.aspx? BibCode $=1851353$

Darden RL (2004) Population genetics of the blue crab in the Gulf of Mexico. PhD dissertation, The University of Southern Mississippi, Hattiesburg, MS

* Doherty PJ, Dufour V, Galzin R, Hixon MA, Meekan MG, Planes S (2004) High mortality during settlement is a population bottleneck for a tropical surgeonfish. Ecology 85:2422-2428

Dudley DL, Judy MH (1971) Occurrence of larval, juvenile, and mature crabs in the vicinity of Beaufort Inlet, North Carolina. NOAA Tech Rep NMFS SSRF-637

*Epifanio CE (1988) Dispersal strategies of two species of swimming crab on the continental shelf adjacent to Delaware Bay. Mar Ecol Prog Ser 49:243-248

Epifanio CE (1995) Transport of blue crab (Callinectes sapidus) larvae in the waters off Mid-Atlantic states. Bull Mar Sci 57:713-725

Epifanio CE, Garvine RW (2001) Larval transport on the Atlantic continental shelf of North America: a review. Estuar Coast Shelf Sci 52:51-77

Epifanio CE, Valenti CC, Pembroke AE (1984) Dispersal and recruitment of blue crab larvae in the Delaware Bay, USA. Estuar Coast Shelf Sci 18:1-12

Epifanio CE, Masse AK, Garvine RW (1989) Transport of blue crab larvae by surface currents off Delaware Bay, USA. Mar Ecol Prog Ser 54:35-41

Feng X, Williams EP, Place AR (2017) High genetic diversity 
and implications for determining population structure in the blue crab Callinectes sapidus. J Shellfish Res 36:231-242

Flaherty KE, Guenther CB (2011) Seasonal distribution and abundance of blue crabs (Callinectes sapidus) in the Tampa Bay Estuary. Gulf Mex Sci 2011:91-110

Forward RB Jr, Tankersley RA (2001) Selective tidal-stream transport of marine animals. Oceanogr Mar Biol Annu Rev 39:305-353

Forward RB Jr, Tankersley RA, Welch JM (2003) Selective tidal-stream transport of blue crab Callinectes sapidus: an overview. Bull Mar Sci 72:347-365

FWRI FIM Inhouse Report (2015) Fisheries-independent monitoring program 2015 annual data summary report. FWRI Inhouse Report No. IHR2016-002. Florida Fish and Wildlife Conservation Commission, Fish and Wildlife Research Institute, St. Petersburg, FL. https://f50006a.eosintl.net/F50006A/OPAC/Details/Record.aspx?BibCode= 1643171

Garavelli L, Studivan MS, Voss JD, Kuba A, Figueiredo J, Chérubin LM (2018) Assessment of mesophotic coral ecosystem connectivity for proposed expansion of a marine sanctuary in the Northwest Gulf of Mexico: larval dynamics. Front Mar Sci 5:174.

Gelpi CG Jr, Condrey RE, Fleeger JW, Dubois SF (2009) Discovery, evaluation, and implications of blue crab, Callinectes sapidus, spawning, hatching, and foraging grounds in federal (US) waters offshore of Louisiana. Bull Mar Sci 85:203-222

Gelpi CG Jr, Fry B, Condrey RE, Fleeger JW, Dubois SF (2013) Using $\delta^{13} \mathrm{C}$ and $\delta^{15} \mathrm{~N}$ to determine the migratory history of offshore Louisiana blue crab spawning stocks. Mar Ecol Prog Ser 494:205-218

Gilbert PS, Lee TN, Podestá GP (1996) Transport of anomalous low salinity waters from the Mississippi River flood of 1993 to the Straits of Florida. Cont Shelf Res 16:1065-1085

G Grey EK, Chiasson SC, Williams HG, Troeger VJ, Taylor CM (2015) Evaluation of blue crab, Callinectes sapidus, megalopal settlement and condition during the Deepwater Horizon oil spil. PLOS ONE 10:e0135791

Guillory V, Perry H, VanderKooy S (2001) The blue crab fishery of the Gulf of Mexico, United States: a regional management plan. Gulf States Marine Fisheries Commission, Publication 96, Ocean Springs, MS

Hasek BE, Rabalais NN (2001) Settlement patterns of brachyuran megalopae in a Louisiana estuary. Estuar Coast 24:796-807

Holstein DM, Paris CB, Vaz AC, Smith TB (2016) Modeling vertical coral connectivity and mesophotic refugia. Coral Reefs 35:23-37

$\mathrm{Hu}$ C, Nelson JR, Johns Chen EZ, Weisberg RH, Müller Karger FE (2005) Mississippi River water in the Florida Straits and in the Gulf Stream off Georgia in summer 2004. Geophys Res Lett 32:L14606

Hunt HL, Scheibling RE (1997) Role of early post-settlement mortality in recruitment of benthic marine invertebrates. Mar Ecol Prog Ser 155:269-301

Johnson DR, Perry HM (1999) Blue crab larval dispersion and retention in the Mississippi Bight. Bull Mar Sci 65: 129-149

Johnson, DR, Perry HM, Lyczkowski-Shultz J, Hanisko D (2009) Red snapper larval transport in the northern Gulf of Mexico. Trans Am Fish Soc 138:458-470

Johnson DR, Perry HM, Lyczkowski-Shultz J (2013) Connections between Campeche Bank and red snapper populations in the Gulf of Mexico via modeled larval trans- port. Trans Am Fish Soc 142:50-58

Jones BT, Gyory J, Grey E, Bartlein M, Ko DS, Nero RW, Taylor CM (2015) Transport of blue crab larvae in the northern Gulf of Mexico during the Deepwater Horizon oil spill. Mar Ecol Prog Ser 527:143-156

Kennedy JP, Garavelli L, Truelove NK, Devlin DJ, Box SJ, Chérubin LM, Feller IC (2017) Contrasting genetic effects of red mangrove (Rhizophora mangle L.) range expansion along West and East Florida. J Biogeogr 44: 335-347

Ko DS, Preller RH, Martin PJ (2003) An experimental realtime intra-Americas sea ocean nowcast/forecast system for coastal prediction. In: Proceedings of the 5th American Meteorological Society conference on coastal atmospheric and oceanic prediction and processes, 6-8 August 2003, Seattle, WA. AMS, Washington, DC, p 97-100

*Kordos LM, Burton RS (1993) Genetic differentiation of Texas gulf coast populations of the blue crab, Callinectes sapidus. Mar Biol 117:227-233

Le Hénaff M, Kourafalou VH (2016) Mississippi waters reaching South Florida reefs under no flood conditions: synthesis of observing and modeling system findings. Ocean Dyn 66:435

*L Hénaff M, Kourafalou VH, Morel Y, Srinivasan A (2012) Simulating the dynamics and intensification of cyclonic Loop Current Frontal Eddies in the Gulf of Mexico. J Geophys Res 117:C02034

Lee TN, Johns E, Wilson D, Williams E, Smith NP (2002) Transport processes linking south Florida coastal ecosystems. In: Porter J, Porter K (eds) Linkages between ecosystems in the South Florida hydroscape. CRC Press, Boca Raton, FL, p 309-342

KLi Y, Nowlin WD Jr, Reid RO (1997) Mean hydrographic fields and their interannual variability over the Texas Louisiana continental shelf in spring, summer and fall. J Geophys Res 102:1027-1104

Lipcius RN, Eggleston DB, Heck KL Jr, Seitz RD, van Montfrans J (2007) Ecology of postlarval and young juvenile blue crabs. In: Kennedy VS, Cronin LE (eds) The blue crab, Callinectes sapidus. University of Maryland Sea Grant Press, College Park, MD, p 535-564

* Little KT, Epifanio CE (1991) Mechanism for the re-invasion of an estuary by two species of brachyuran megalopae. Mar Ecol Prog Ser 68:235-242

* Lowe WH, Allendorf FW (2010) What can genetics tell us about population connectivity? Mol Ecol 19:3038-3051

McConaugha JR Jr, Johnson DF, Provenzano AJ, Maris RC (1983) Seasonal distribution of larvae of Callinectes sapidus (Crustacea: Decapoda) in the waters adjacent Chesapeake Bay. J Crustac Biol 3:582-591

McMillen-Jackson AL, Bert TM (2004) Mitochondrial DNA variation and population genetic structure of the blue crab Callinectes sapidus in the eastern United States. Mar Biol 145:769-777

*McMillen-Jackson AL, Bert TM, Steele P (1994) Population genetics of the blue crab Callinectes sapidus: modest population structuring in a background of high gene flow. Mar Biol 118:53-65

*Morey SL, Schroeder WW, O'Brien JJ, Zavala Hidalgo J (2003) The annual cycle of riverine influence in the eastern Gulf of Mexico basin. Geophys Res Lett 30:1867

* Morgan SG, Zimmer-Faust RK, Heck KL Jr, Coen LD (1996) Population regulation of blue crabs Callinectes sapidus in the northern Gulf of Mexico: postlarval supply. Mar Ecol Prog Ser 133:73-88 
Nero RW, Cook M, Coleman AT, Solangi M, Hardy H (2013) Using an ocean model to predict likely drift tracks of sea turtle carcasses in the north central Gulf of Mexico. Endang Species Res 21:191-203

North EW, Schlag Z, Hood RR, Li M, Zhong L, Gross T, Kennedy VS (2008) Vertical swimming behavior influences the dispersal of simulated oyster larvae in a coupled particle-tracking and hydrodynamic model of Chesapeake Bay. Mar Ecol Prog Ser 359: 99-115

Nowlin WD Jr, Jochens AE, DiMarco SF (2005) Low frequency circulation over the Texas Louisiana continental shelf. In: Sturges W, Lugo-Fernandez A (eds) Circulation of the Gulf of Mexico: observations and models. Geophysical Monograph Series Vol 161. AGU, Washington, DC, p 219-240

Ogburn MB, Habegger LC (2015) Reproductive status of Callinectes sapidus as an indicator of spawning habitat in the South Atlantic Bight, USA. Estuar Coast 38:2059-2069

Ohlmann JC, Niiler PP (2005) Circulation over the continental shelf in the northern Gulf of Mexico. Prog Oceanogr 64:45-81

Ohlmann JC, Niiler PP, Fox CA, Leben RB (2001) Eddy energy and shelf interactions in the Gulf of Mexico. J Geophys Res 106:2605-2620

Okubo A (1971) Ocean diffusion diagrams. Deep-Sea Res 18:789-802

* Ortner PB, Lee TN, Milne PJ, Zika RG and others (1995) Mississippi River flood waters that reached the Gulf Stream. J Geophys Res 100:13595-13601

Paris CB, Helgers J, van Sebille E, Srinivasan A (2013) The connectivity modeling system: a probabilistic modeling tool for the multi-scale tracking of biotic and abiotic variability in the ocean. Environ Model Softw 42:47-54

Perry HM, VanderKooy S (2015) The blue crab fishery of the Gulf of Mexico, United States: a regional management plan. Publication No. 243. Gulf States Marine Fisheries Commission, Ocean Springs, MS

Perry HM, Eleuterius CK, Trigg CB, Warren JR (1995) Settlement patterns of Callinectes sapidus megalopae in Mississippi Sound: 1991, 1992. Bull Mar Sci 57:821-833

Perry HM, Johnson DR, Larsen KM, Trigg CB, Vukovich F (2003) Blue crab larval dispersion and retention in the Mississippi Bight: testing the hypothesis. Bull Mar Sci 72: 331-346

Pineda J, Hare J, Sponaugle S (2007) Larval transport and dispersal in the coastal ocean and consequences for population connectivity. Oceanography (Wash DC) 20:22-39

Rabalais NN, Burditt FR Jr, Coen LD, Cole BE, Eleuterius C, Heck KL Jr (1995) Settlement of Callinectes sapidus megalopae on artificial collectors in four Gulf of Mexico estuaries. Bull Mar Sci 57:855-876

Scheltema RS (1986) Long-distance dispersal by planktonic larvae of shoal-water benthic invertebrates among the Central Pacific islands. Bull Mar Sci 39:241-256

Schiller RV, Kourafalou VH (2014) Loop Current impact on the transport of Mississippi River waters. J Coast Res 30: 1287-1306

Schiller RV, Kourafalou VH, Hogan P, Walker ND (2011) The dynamics of the Mississippi River plume: impact of topography, wind and offshore forcing on the fate of plume waters. J Geophys Res 116:C06029

Spitzer PM, Heck KLJ, Valentine JF (2003) Then and now: a

Editorial responsibility: Romuald Lipcius,

Gloucester Point, Virginia, USA comparison of patterns in blue crab post-larval abundance and post-settlement mortality during the early and late 1990s in the Mobile Bay System. Bull Mar 9: 435-452

* Sponaugle S, Paris C, Walter KD, Kourafalou V, D'Alessandro E (2012) Observed and modeled larval settlement of a reef fish to the Florida Keys. Mar Ecol Prog Ser 453: 201-212

Steele P (1991) Population dynamics and migration of the blue crab Callinectes sapidus Rathbun, in the eastern Gulf of Mexico. Proc Annu Gulf Caribb Fish Inst 40:241-244

Steele P, Bert TM (1994) Population ecology of the blue crab, Callinectes sapidus Rathbun, in a subtropical estuary: population structure, aspects of reproduction, and habitat partitioning. Fla Mar Res Publ 51:1-24

Steele P, Perry HM (1990) The blue crab fishery of the Gulf of Mexico United States: a regional management plan. Publication No. 21. Gulf States Marine Fisheries Commission, Ocean Springs, MS

Sulkin SD, Van Heukelem W, Kelly P, Van Heukelem L (1980) The behavioral basis of larval recruitment in the crab, Callinectes sapidus Rathbun: a laboratory investigation of ontogenetic changes in geotaxis and barokinesis. Biol Bull (Woods Hole) 159:402-417

Tagatz ME (1968) Biology of the blue crab, Callinectes sapidus Rathbun, in the St. John's River, Florida. Fish Bull 67: 17-33

*Tilburg CE, Whitney MM, Reager JT (2005) The physics of blue crab larval recruitment in Delaware Bay: a model study. J Mar Res 63:471-495

Tilburg CE, Dittel AI, Epifanio CE (2007) Retention of crab larvae in a coastal null zone. Estuar Coast Shelf Sci 72: 570-578

VanderKooy S (2013) Gulf of Mexico blue crab stock assessment report. Publication No. 215. Gulf States Marine Fisheries Commission, Ocean Springs, MS

*Walker ND, Fargion G, Rouse LJ Jr, Biggs D (1994) Circulation of Mississippi River water discharged into the northern Gulf of Mexico by the great flood of summer 1993. Eos (Wash DC) 75:409-415

* Walker ND, Huh OK, Rouse LJ Jr, Murray SP (1996) Evolution and structure of a coastal squirt off the Mississippi River delta: northern Gulf of Mexico. J Geophys Res 101: 20643-20655

Walker ND, Wiseman WJ Jr, Rouse LJ Jr, Babin A (2005) Effects of river discharge, wind stress, and slope eddies on circulation and satellite observed structure of the Mississippi River plume. J Coast Res 216:1228-1244

Weisberg RH, Li Z, Muller-Karger FE (2001) West Florida shelf response to local wind forcing: April 1998. J Geophys Res 106:31239-31262

Weisberg RH, He R, Liu Y, Virmani J (2005) West Florida shelf circulation on synoptic, seasonal, and inter-annual time scales. Geophys Monogr 161:325-347

Y Yeung C, Criales MM, Lee TN (2000) Unusual larval abundance of Scyllarides nodifer and Albunea sp. during the intrusion of low-salinity Mississippi flood water in the Florida Keys in September 1993: insight into larval transport from upstream. J Geophys Res 105:28741-28758

Zaron ED, Fitzpatrick PJ, Cross SL (2015) Initial evaluations of a Gulf of Mexico/Caribbean ocean forecast system in the context of the Deepwater Horizon disaster. Front Earth Sci 9:605-636

Submitted: September 24, 2018; Accepted: July 1, 2019

Proofs received from author(s): August 27, 2019 